\title{
The Imbalance between n-6/n-3 Polyunsaturated Fatty Acids and Inflammatory Bowel Disease: A Comprehensive Review and Future Therapeutic Perspectives
}

\author{
Eleonora Scaioli, Elisa Liverani and Andrea Belluzzi * \\ Department of Medical and Surgical Sciences, St. Orsola-Malpighi Hospital, University of Bologna, \\ 40138 Bologna, Italy; elescaio@gmail.com (E.S.); elisa.liverani5@studio.unibo.it (E.L.) \\ * Correspondence: andrea.belluzzi@aosp.bo.it; Tel.: +390-512-143-873; Fax: +390-512-143-873
}

Received: 13 November 2017; Accepted: 29 November 2017; Published: 5 December 2017

\begin{abstract}
Eating habits have changed dramatically over the years, leading to an imbalance in the ratio of $n-6 / n-3$ polyunsaturated fatty acids (PUFAs) in favour of n-6 PUFAs, particularly in the Western diet. Meanwhile, the incidence of inflammatory bowel disease (IBD) is increasing worldwide. Recent epidemiological data indicate the potential beneficial effect of $n-3$ PUFAs in ulcerative colitis (UC) prevention, whereas consumption of a higher ratio of n-6 PUFAs versus n-3 PUFAs has been associated with an increased UC incidence. The long-chain dietary n-3 PUFAs are the major components of n-3 fish oil and have been shown to have anti-inflammatory properties in several chronic inflammatory disorders, being involved in the regulation of immunological and inflammatory responses. Despite experimental evidence implying biological plausibility, clinical data are still controversial, especially in Crohn's disease. Clinical trials of fish-oil derivatives in IBD have produced mixed results, showing beneficial effects, but failing to demonstrate a clear protective effect in preventing clinical relapse. Such data are insufficient to make a recommendation for the use of n-3 PUFAs in clinical practice. Here, we present the findings of a comprehensive literature search on the role of $n-3$ PUFAs in IBD development and treatment, and highlight new therapeutic perspectives.
\end{abstract}

Keywords: inflammatory bowel disease; ulcerative colitis; Crohn's disease; $n-3$ polyunsaturated fatty acids; omega-3 fatty acids

\section{Introduction}

Eating habits have dramatically changed over the years, leading to an imbalance in the ratio of $n-6 / n-3$ polyunsaturated fatty acids (PUFAs) in favour of n-6 PUFAs, particularly in the Western diet [1]. These changing alimentary habits have coincided with a worldwide increase in the incidence of inflammatory bowel disease (IBD) in recent decades [2]. Consumption of a higher ratio of pro-inflammatory n-6 PUFAs, such as linoleic acid (LA) and arachidonic acid (AA), to n-3 PUFAs has been associated with an increased incidence of ulcerative colitis (UC) [3,4].

Recent epidemiological data indicate the potential beneficial effect of n-3 PUFAs in IBD, particularly in UC where a high intake of n-3 PUFAs may lower the incidence of the disease [5].

The long chain dietary n-3 PUFAs, in particular eicosapentaenoic acid (EPA) and docosahexaenoic acid (DHA), are the major components of $\mathrm{n}-3$ fish oil and have been shown to have anti-inflammatory properties in several chronic inflammatory disorders, such as asthma and rheumatoid arthritis [6]. EPA and DHA are definitively involved in the regulation of immunological and inflammatory responses [7]; they inhibit genes that start the inflammatory process [8] and alter the composition of cell membranes by displacing n-6 PUFAs, influencing lipid raft formation in cell signalling [9]. Some of 
these anti-inflammatory effects of n-3 PUFAs may be mediated by competition with $n-6$ PUFAs, because $n-3$ PUFAs act as a competitive substrate for the metabolism of n-6 PUFAs [10]. More recently, new metabolic pathways for n-3 PUFAs have been reported, leading to production of inflammatory resolving mediators called resolvins, defensins, and maresins [11,12]. Despite experimental evidence implying biological plausibility, clinical data on the benefits of n-3 PUFAs in IBD are still controversial and conflicting, especially in Crohn's disease (CD) $[13,14]$. Clinical trials of fish-oil derivatives in IBD have produced mixed results, showing beneficial effects, such as a reduction of inflammation and decreased need for steroid therapy, but also failing to demonstrate a clear protective effect in preventing clinical relapse [15-25]. Such data are insufficient to make a recommendation for the use of n-3 PUFAs in clinical practice [13,14,26-28]. We have carried out a comprehensive literature search regarding the anti-inflammatory mechanisms of action of n-3 PUFAs and, specifically, their utilisation for dampening down chronic inflammatory activity in IBD, and we present a critical analysis of clinical trials with n-3 PUFAs in this field, highlighting new therapeutic perspectives.

\subsection{IBD Epidemiology and Dietary Intake of n-6/n-3 PUFAs}

The incidences of $\mathrm{UC}$ and $\mathrm{CD}$ are increasing worldwide, reaching 20 new cases per 100,000 person-years in Western countries [2], as well as in countries where IBD was previously thought to be uncommon [29]. Furthermore, data from epidemiological studies of migrants to higher-IBD-prevalence countries show an increasing incidence of IBD [30,31]. These findings support the hypothesis of an environmental trigger for IBD development in genetically susceptible individuals.

Among many possible environmental factors, diet is one of the most important. Eating habits have changed dramatically over the centuries, moving from a Paleolithic diet (prior to the agricultural revolution, and comprising primarily meat, fish, vegetables, and fruit) to a Western diet (during the modern, postindustrial-revolution era, with increased consumption of grains and refined sugars) [32].

Based on the premise that human genetics have scarcely changed over the last 3000 years, modern humans should genetically be better adapted to the diet of their Paleolithic ancestors [32]. However, dietary changes stemming from the agricultural revolution have markedly changed patterns of food consumption, leading to an "evolutionary discordance" that may have contributed to the dramatic increase in chronic inflammatory diseases seen over the last century [33-35].

Supporting this concept, a recent pooled cross-sectional study of 646 subjects undergoing elective outpatient colonoscopy found significantly lower levels of systemic inflammation and oxidative stress in those patients who followed a more Paleolithic- and Mediterranean-like diet, compared with other types of diets [36].

One of the most contrasting elements between the Paleolithic diet and the Western diet is the differing ratios of n- 6 and n-3 PUFAs, with the former diet being in perfect balance (1:1), while the latter is deeply unbalanced in favour of n-6 PUFAs (20:1) [37].

Blasbalg et al. [1] perfectly illustrate the profound change in PUFAs ratio during the last century in favour of n-6 PUFAs; indeed, the estimated per capita consumption of soybean oil increased $>1000$ fold from 1909 to 1999. The percentage contribution of energy from the n-6 PUFA, LA, increased from $2.79 \%$ to $7.21 \%(p<0.000001)$, whereas that of the n-3 PUFA, $\alpha$ linolenic acid (ALA), increased from $0.39 \%$ to $0.72 \%$ using the same model, and the ratio of LA to ALA increased from 6.4 in 1909 to 10.0 in 1999. The increased consumption of LA from soybean oil has likely decreased tissue concentrations of EPA and DHA during the 20th century, and the omega-3 index [38] (a direct measure of erythrocyte EPA + DHA as a percentage of total fatty acids) declined from $8.28 \%$ in 1909 to $3.84 \%$ in 1999 .

Since the 1990s, researchers have sought to define a correlation between the intake of n-3 and n-6 PUFAs and the incidence of IBD. Initial studies were retrospective and/or case-controlled in design, with poor reliability [39-41]; however, four recent large, prospective, epidemiological studies have contributed to better defining the role of PUFAs intake in the incidence of IBD.

Tjonneland et al. [4] analysed data from food frequency questionnaires completed by more than 200,000 participants in a prospective, multicenter cohort study, the European Prospective Investigation 
into Cancer and Nutrition (EPIC), who were followed up for diagnosis of UC. A total of 126 participants developed UC ( $47 \%$ women) after a median follow up of 4 years. Each case was matched with four controls and the risk of disease calculated by quartile. The highest quartile of intake of the n-6 PUFA, LA, was associated with an increased risk of UC (odds ratio (OR) 2.49, 95\% confidence interval (CI): $1.23-5.07 ; p=0.01$ ) in both genders. In contrast, increased dietary intake of the n-3 PUFA, DHA, was associated with a reduced risk of UC; for the highest quartile, the OR was 0.23 (95\% CI: 0.06-0.97). In this study, the main finding was that the highest intake of the n-6 PUFA, LA, was associated with more than a doubling of the risk of developing UC. Findings on n-3 PUFAs were less compelling, which may be due to a reduced sample size because data on certain n-3 PUFAs were not available from one centre.

John et al. [42] investigated more than 25,600 participants living in Norfolk, UK, who completed seven-day food diaries, among whom 22 incident cases of UC were identified after a median follow-up time of 4.2 years. A statistically significant, dose-dependent, negative association was found between increased intake of DHA and the risk of developing UC. The highest tertile of DHA intake showed a reduction in risk of $83 \%$ (OR $0.17,95 \%$ CI: $0.04-0.78 ; p=0.02$ ). Moreover, there were negative associations for UC with total n-3 PUFAs (OR 0.56, 95\% CI: 0.28-1.13; $p=0.10$ ) and EPA (OR 0.53, 95\% CI: $0.27-1.03 ; p=0.06$ ), which were of borderline statistical significance.

Ananthakrishnan et al. [5] conducted a prospective study of women enrolled in the Nurses' Health Study cohorts. Diet was prospectively ascertained every 4 years using a validated semi-quantitative food frequency questionnaire. Among 170,800 women, the authors confirmed 269 incident cases of CD and 338 incident cases of UC over 26 years, and 3,317,338 person-years of follow up. Intake of n-3 PUFAs (docosapentaenoic acid (DPA), EPA, and DHA) was inversely associated with risk of UC; those with the highest intake had reduced incidence of UC (hazard ratio (HR) 0.72, 95\% CI: 0.51-1.02; $p($ trend $)=0.13$. Moreover, compared to the lowest quintile of the ratio between $\mathrm{n}-3$ and $\mathrm{n}-6$ PUFAs, women in the highest quintile had an HR of 0.69 (95\% CI: 0.49-0.98; $p$ (trend) $=0.03$ ) for UC. In contrast, intake of each individual fatty acid (either n-3 or n-6 PUFAs) was not associated with risk of CD.

Chan et al. [43] investigated 229,700 participants from the EPIC cohort, using a validated food frequency questionnaire that assessed dietary intake of DHA and other fatty acids, to identify those who developed incident CD. The cohort was recruited between 1991-1998 and monitored until June 2004 in a nested case-control analysis; each case was matched with four controls. Seventy-three participants developed $\mathrm{CD}$. The highest quintile of DHA intake was inversely associated with development of CD (OR $0.07,95 \%$ CI: 0.02-0.81). No other associations were found with respect to other dietary fatty acids.

Hou et al. [44] carried out a systematic review of the literature on dietary intake and the risk of developing IBD. Among 19 identified studies, the authors reported an increased risk of developing UC with high intake of total fat, n-6 PUFAs, and meat, as well as an increased risk of CD with a high intake of n-6 PUFAs, saturated fats, and meat. No evidence of a protective effect of dietary n-3 PUFAs pre-illness was found.

\section{2. n-6/n-3 PUFAs and Inflammatory Processes in IBD}

\subsubsection{Eicosanoid Pathways and Inflammation}

n-3 and n-6 PUFAs are defined by the position of the first double bond in the carbon chain. The human body can produce all but 2 PUFAs: the essential fatty acids, LA, the precursor to the $n-6$ series, and ALA, the precursor to the n-3 series. Eicosanoids are key lipid mediators generated from the $n-6$ and $n-3$ PUFAs that have important roles in immune regulation and inflammation. They are synthesised from 20-carbon PUFAs using AA as the major substrate. Free AA is metabolised by three main classes of enzymes: (1) cyclooxygenases (COX), which produce prostaglandins (PG) and thromboxanes (TX); (2) lipoxygenases (LOX), which generate leukotrienes (LT), hydroxyeicosatetraenoic acid (HETEs), and lipoxins (LX); and (3) p450 epoxygenases, which synthesise epoxyeicosatrienoic acids (EETs). These eicosanoids are deeply involved in the inflammatory processes 
of IBD; they have a potent chemotactic action and an ability to recruit neutrophils, increase vascular permeability, promote platelet aggregation, cause oedema, and induce the release of pro-inflammatory substances, such as cytokines (soluble proteins influencing the immune system), which lead to the production of chronic inflammatory mediators, such as interleukin (IL) $1 \beta, 6$, and 8 , and tumor necrosis factor $\alpha(\mathrm{TNF} \alpha)[11,45]$.

Findings suggest that the colonic mucosa in active UC are associated with a marked increase in the availability of n-6 PUFAs, specifically AA ( $p<0.001)$; conversely, n-3 PUFAs, specifically EPA, are less represented $(p<0.01)$ and the ratio of AA/EPA is higher $(p<0.001)$ with respect to controls [46].

n-3 PUFAs also serve as precursors of a class of eicosanoids with very little or no inflammatory properties, such as LTB5 [47].

It has also been widely demonstrated that n-3 PUFAs such as EPA and DHA are able to inhibit inflammatory cytokine production [48]. The incorporation of EPA and DHA into human inflammatory cells occurs in a dose-responsive fashion and partly displaces AA [49].

Dietary supplementation with n-3 PUFAs results in decreased production of PGE2, TXB2, and HETEs [11].

Moreover, new n-3 PUFAs-derived anti-inflammatory molecules, collectively termed specialised pro-resolving mediators (SPMs) and including resolvins, protectins, and maresins, have been identified [12]. SPMs counteract pro-inflammatory chemical mediators, reducing the magnitude and duration of inflammation, increasing production of anti-inflammatory cytokines (i.e., IL10), and stimulating wound healing, tissue regeneration, and re-epithelialisation. Figure 1 summarises the pathways of synthesis for the n-3 and n-6 PUFAs eicosanoids and the SPMs.

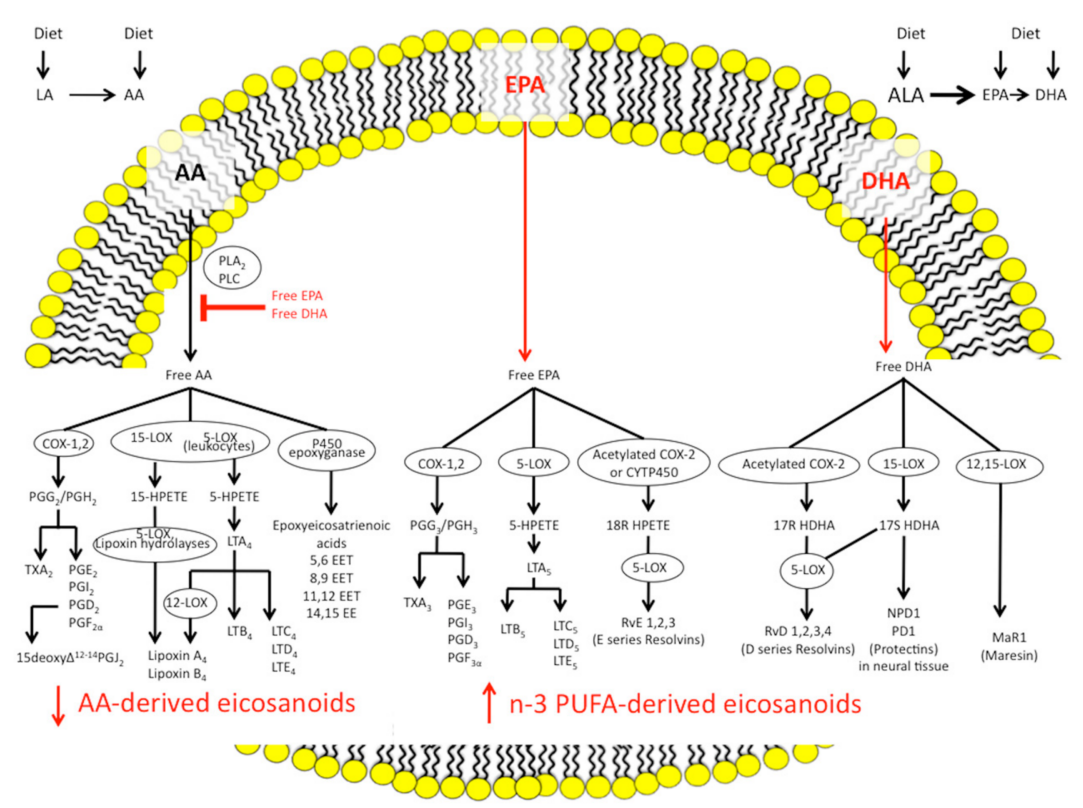

Figure 1. Outline of the pathways of synthesis for the $n-3$ and $n-6$ polyunsaturated fatty acids eicosanoids and the specialised pro-resolving mediators. AA, arachidonic acid; ALA, $\alpha$-linolenic acid; COX, cyclooxygenase; CYTP450, cytochrome P450 enzymes; DHA, docosahexaenoic acid; EET, epoxyeicosatrienoic acid; EPA, eicosapentaenoic acid; HDHA, dihydroxy-docosahexaenoic acid; HPETE, hydroperoxyeicosatetraenoic acid; LA, linoleic acid; LT, leukotriene; LOX, lipoxygenase; MaR, maresin; NPD1, neuroprotectin D1; PD1, protectin D1; PG, prostaglandin; PLA2, phospholipase A2; PLC, phospholipase C; PUFA, polyunsaturated fatty acid; RvD, D series resolvins; RvE, E series resolvins; TX, thromboxane. 


\subsection{2. n-3 PUFAs and the Endocannabinoid Epoxides Pathway}

A very recent study reported on endogenous production of a previously unknown class of n-3 PUFAs-derived lipid metabolites, originating from cross-talk between endocannabinoid and cytochrome P450 (CYTP450) oxygenase metabolic pathways [50]. The n-3 endocannabinoid epoxides have been shown to dose-dependently decrease production of the pro-inflammatory cytokine, IL6, while increasing production of the anti-inflammatory cytokine, IL10. Moreover, n-3 endocannabinoid epoxides may exert anti-angiogenic effects in human microvascular endothelial cells. Taken together, these newly discovered n-3 endocannabinoid epoxides are expected to play a critical role during inflammation in vivo.

\subsection{3. n-3 PUFAs and Inflammatory Gene Expression}

The two main transcription factors involved in IBD inflammatory processes are nuclear factor $\mathrm{kB}$ $(\mathrm{NFKB})$, which is proinflammatory, and peroxisome proliferator activated receptor gamma (PPAR- $\gamma$ ), which is antinflammatory; both are expressed in the colon. PPAR- $\gamma$ regulates inflammation by inhibiting NFKB [51,52]. Reduced expression of PPAR- $\gamma$ has been reported in patients with UC and CD [53]. Many of the effects of n-3 PUFAs on the production of inflammatory mediators appear to be related to altered expression of genes encoding these mediators. n-3 PUFAs may modify the activity of the transcription factors NFKB and PPAR- $\gamma$, in particular, by promoting PPAR- $\gamma$ gene transcription and inhibiting NFkB activation [54,55].

Knock et al. [56] compared the effect of EPA supplementation with that of oleic acid (OA) as a control in IL10-encoding gene-deficient mice. Mice fed an OA-supplemented diet had decreased expression of genes encoding antioxidant enzymes, as well as enzymes involved in detoxification, when compared with wild-type mice on the same diet. Conversely, EPA supplementation up-regulated the expression of these same enzymes, showing a potent anti-inflammatory effect on colon tissue.

Costea et al. [57] investigated whether variation in genes that control n-3 PUFAs metabolism (CYP4F3, FADS1, FADS2), together with alterations in the dietary ratio of $n-6 / n-3$ PUFAs, confer susceptibility to $C D$. One-hundred and eighty-two children newly diagnosed with $C D$ and 250 controls were studied, investigating 15 single nucleotide polymorphisms (SNPs) across these 3 genes. Logistic regression analysis showed that a higher ratio of n-6/n-3 PUFAs was associated with increased risk of CD (OR 1.63, 95\% CI: 1.01-2.62; $p=0.044)$. The investigators observed a significant interaction $(p<0.05)$ involving SNPs, suggesting that the association between dietary $n-6 / n-3$ PUFAs ratio and CD was influenced by the presence of specific variants of CYP4F3 and FADS2. The CYP4F3 gene is expressed in neutrophils, monocytes, and intestine, and is an important modulator of the inflammatory process via its ability to inactivate LTB4 [58]. The ability of CYTP450 F3 to detoxify those fatty acids that are intimately associated with inflammation makes it a relevant candidate for the treatment of $\mathrm{CD}$. The FADS2 gene is a key PUFAs metabolic gene and desaturase that catalyses the first step in the conversion of essential PUFAs such as n-6 LA and n-3 ALA into longer chain n-6 and n-3 PUFAs. It has been observed that variations in this gene are associated with endogenous serum/plasma levels of EPA, DPA, DHA, and different PUFAs ratios [59]. The elevated risk for CD associated with increased dietary ratio of n-6/n-3 PUFAs in those individuals with particular FADS2 SNPs indeed suggests that lower endogenous production of $n-3$ PUFAs, combined with a higher $n-6 / n-3$ dietary ratio, may increase the risk of $C D$ in children [57].

Zhang et al. [60] reviewed the mechanism involved in the endogenous synthesis of long-chain PUFAs and showed that this is strongly dependent on the action of the fatty acid desaturase (FADS) and elongase (ELOVL) enzymes. Polymorphisms in the FADS and ELOVL genes can limit accumulation of long-chain PUFAs. The genes mediating the endogenous synthesis of PUFAs contribute to wide variability in the efficiency of this process, likely influenced by variation in FADS and ELOVL genes, as well as the metabolic state. In the current era of mass individual migration and easy availability of imported international foodstuffs, individuals with genotypes adapted to a particular diet that contains high or low amounts of long-chain PUFAs may find themselves exposed to other diets with 
a different PUFAs content than they are used to. In these cases, optimum nutrition depends on the detailed genetic control and efficiency of the process of long-chain PUFAs conversion.

Grimble et al. [61] investigated the relationship between TNF $\alpha$ gene polymorphisms and n-3 PUFAs. TNF $\alpha$ production varies widely among healthy individuals, and this study showed that the ability of n-3 PUFAs to suppress TNF $\alpha$ production from peripheral blood mononuclear cells in healthy men is deeply influenced by inherent TNF $\alpha$ production and TNF $\alpha$ gene polymorphisms. $\mathrm{TNF} \alpha$ production decreased significantly after fish-oil supplementation in subjects who had a higher basal level of TNF $\alpha$ production, whereas the effects of dietary n-3 PUFAs intake were much less pronounced in subjects with lower basal TNF $\alpha$ production and paradoxically increased in those in the lowest tertile of basal TNF $\alpha$ production.

\subsection{4. n-3 PUFAs and Adaptive Immunity}

n-3 PUFAs are able to modulate chemotaxis of immune cells, specifically a time-dependent decrease in chemotaxis of human neutrophils and monocytes towards various chemoattractants, including LTB4 [62].

Moreover, cell culture and animal feeding studies reported decreased expression of some adhesion molecules, such as vascular cell adhesion molecule 1 (VCAM-1), on the surfaces of monocytes, macrophages, lymphocytes, and endothelial cells following exposure to marine n-3 PUFAs [63]. This effect was independent of eicosanoid production and antioxidant status [64].

\subsection{5. n-3 PUFAs, Innate Immunity, the Inflammasome, and Microbiome}

IBD patients exhibit aberrant innate immunity [65], as well as abnormal gut microbiome composition and activity [66].

The family of membrane-bound Toll-like receptors (TLRs) are considered to be an interface between the intestinal epithelial barrier, microbiota, and the immune system: TLR signalling pathways can be activated by microbial pathogens, while genetic defects in TLRs can cause a breakdown in tolerance to normally non-pathogenic intestinal microbiota in genetically predisposed individuals [67]. Both situations can be involved in IBD pathogenesis.

Nucleotide-binding oligomerisation domain 2 (NOD2), which is an intracellular sensor of bacterial peptidoglycan, was identified as a gene associated with susceptibility to CD [68].

It is postulated that the ability of CD-associated variants of NOD2 to recognise microbial components is likely to be impaired to varying degrees, resulting in the inappropriate activation of NFkB in monocytes [69]. Both TLR and NOD2 signalling are involved in increased intestinal permeability and alteration of tight junction proteins.

In vitro evidence suggests that certain types of fatty acids modulate NOD and TLR-mediated inflammation. Saturated fatty acid and n-6 PUFAs may exacerbate intestinal inflammation by upregulating TLR and NOD pathways, and increase intestinal permeability as a result of an alteration of tight junction protein [70]. n-3 PUFAs modulate membrane receptors and, in particular, strongly inhibit the expression of TLR4 [71] and dampen NOD2 signalling by blocking the release of NFKB from a protein kinase pathway [mitogen-activated protein kinase (MAPK)] [72].

The inflammasome is a cytosolic protein complex composed of NOD-like receptors (NLRs) that is a central regulator of innate immunity and inflammation [73]. In response to microbial and danger signals, it promotes caspase 1 activation, leading to the release of several pro-inflammatory cytokines (i.e., IL1 $\beta$, IL18).

In IBD patients, the NLRP3 inflammasome has been found to be chronically activated [74]. A high-fat diet activates the NLRP3 inflammasome in macrophages [75]; n-3 PUFAs, mainly EPA, are able to abolish NLRP3 inflammasome activation, thus inhibiting subsequent release of cytokines [76].

It is already established that a Western diet may influence intestinal microflora, producing dysbiosis [77], and a metabolomics study reported that metabolites produced by the gut microbiome in CD patients strongly correlated with the content of dietetic AA and LA [78]. Conversely, in an 
animal model $[79,80]$ and in a small human study [81], the administration of n-3 PUFAs altered gut microbiome and improved dysbiosis through enrichment of Lactobacillus species and a reduction in bacteria of the Bacteroidaceae family.

Very recent findings show a negative association between Akkermansia abundance and levels of n-6 PUFAs [82]. Watson et al. [83] investigated the effect of n-3 PUFAs supplementation for 8 weeks on the fecal microbiome in 22 middle-aged, healthy volunteers, reporting a reversible increase in several short-chain fatty acid-producing bacteria (Bifidobacterium, Lachnospira, Roseburia, and Lactobacillus) without a significant change in microbial diversity.

These data support the concept that n-3 PUFAs may directly modulate innate immunity, whereas the evidence that supports their influence on microbiome composition is still preliminary, although encouraging. Figure 2 summarises the n-3 PUFAs targets of intestinal innate immunity.

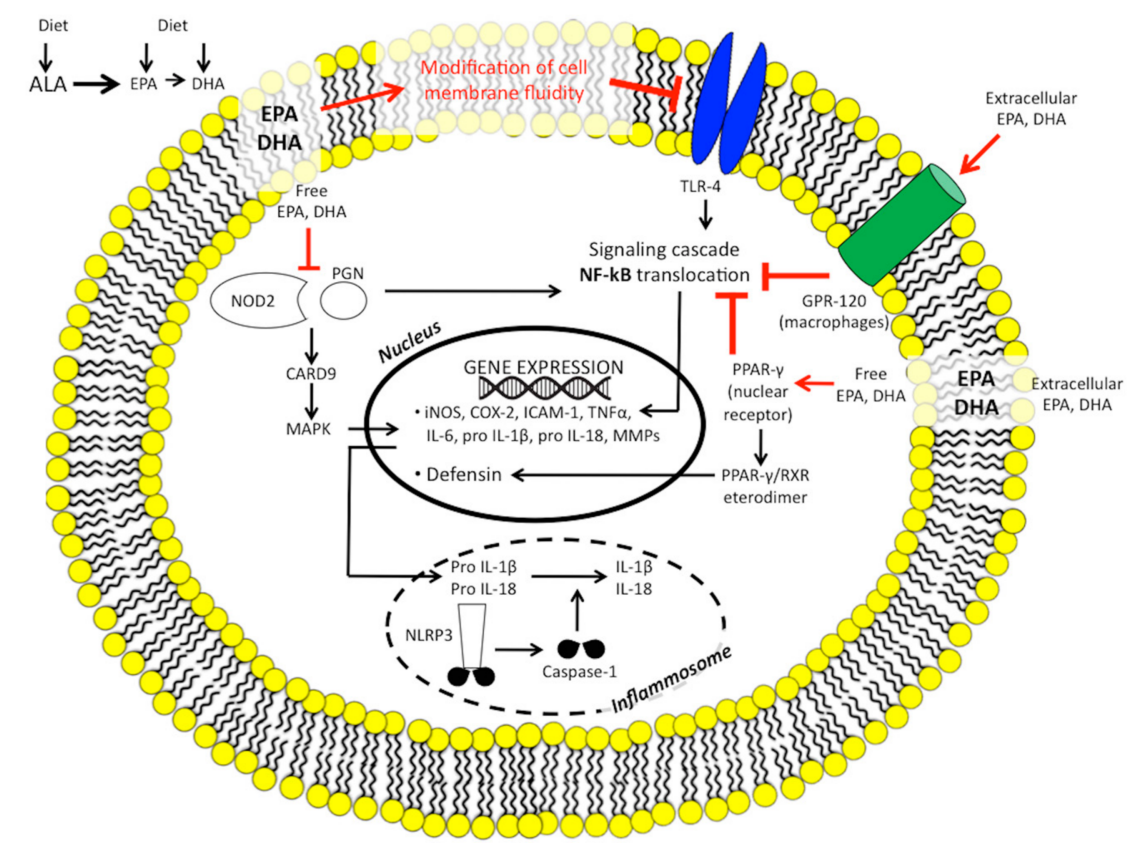

Figure 2. The n-3 polyunsaturated fatty acid targets of intestinal innate immunity. ALA, $\alpha$-linolenic acid; CARD, caspase recognition domain; COX, cyclooxygenase; DHA, docosahexaenoic acid; EPA, eicosapentaenoic acid; GPR, G-protein coupled receptor; ICAM, intracellular adhesion molecule; IL, interleukin; iNOS, inducible nitric oxide synthase; MAPK, mitogen-activated protein kinase; MMPs, matrix metalloproteinase; NF-kB, nuclear factor kB; NLRP3, NOD-like receptor protein 3; NOD2, nucleotide-binding oligomerisation domain 2; PGN, bacterial peptidoglycan; PPAR- $\gamma$, peroxisome proliferator-activated receptor $\gamma$; RXR, retinoid X receptor; TLR, toll-like receptor; TNF $\alpha$, tumour necrosis factor $\alpha$.

\subsection{6. n-3 PUFAs and Nitric Oxide}

Nitric oxide (NO) is a free radical synthesised from L-arginine by nitric oxide synthase (NOS) that is involved in many biological functions. Excessive amounts of NO lead to inflammation related-tissue damage, and NO has been proposed to play an important role in the inflammatory processes involved in the pathogenesis of UC [84]. n-3 PUFAs can act at the nuclear level to affect expression of genes involved in different metabolic pathways, and regulation of inducible NOS gene expression has been shown to be markedly decreased after administration of n-3 PUFAs, leading to a subsequent decrease in NO production [85]. 


\section{3. $n-6$ and $n-3$ PUFAs in IBD Clinical Trials}

To better understand the complexity of the disease and the need for well-designed trials in IBD, the first study we would mention is a double-blind, randomised, placebo-controlled trial in which both essential n-3 and n-6 PUFAs were administered together in a group of UC patients, with the aim of reducing the frequency of disease relapse. Middleton et al. [86] treated 63 UC patients with 6 capsules per day of n- 6 gamma linolenic acid (GLA) together with EPA and DHA (500 mg each) versus 6 capsules daily of a sunflower oil placebo, itself a rich source of n-6 PUFAs. As it was possible to predict based on confounding premises, the study showed a similar relapse rate in the two groups after 12 months and no changes in sigmoidoscopic grade from baseline.

Despite the experimental evidence implying the biological plausibility of employing n-3 PUFAs for IBD, clinical data are still controversial and conflicting.

Investigations into IBD began at the end of the 1980s. The first evidence of clinical benefit of n-3 PUFAs came from McCall [18] who, in an open-label study, gave 3-4 g of EPA daily (16-24 capsules of fish oil as triacylglycerol) for 12 weeks to 6 patients with active UC. A significant improvement in symptoms and histological appearance was observed, along with a significant fall in neutrophil LTB4 production.

In the 1990s, Salomon et al. [20], in another open-label study, administered fish oil-derived n-3 PUFAs to 10 UC patients who were refractory to conventional treatment (steroids and salicylates), and obtained a significant improvement in all activity parameters in 7 of 10 patients. The first prospective, controlled, double-blind study was published by Lorenz et al. [23] who treated 39 patients with IBD (of whom 29 had CD) in different stages of clinical activity in a 7-month, placebo-controlled, crossover trial. Patients were randomised to either $3.2 \mathrm{~g}$ daily of n-3 PUFAs or olive oil as placebo. Conventional treatment was discontinued whenever possible or minimised to a constant low level for at least 3 weeks before the study until completion. There was a one-month wash out-period prior to switching treatments. At the end of the study, clinical activity expressed by Crohn's Disease Activity Index (CDAI) [87] was unchanged in patients with CD after n-3 PUFAs supplementation. However, a limitation in the design of this cross-over study was the very short wash-out period between the two treatments. This would not allow a complete displacement of the extra n-3 PUFAs from cellular membranes and could have interfered with the final results of the study. It has previously been shown that inhibition of cytokine production by n-3 PUFAs persists for more than 10 weeks after suspension of treatment with n-3 PUFAs [48]. Hawthorne et al. [17] published the first large placebo-controlled study in 1992. In this study, 96 UC patients in different activity stages were enrolled and were given $4.5 \mathrm{~g}$ daily of EPA as triacylglycerol for 1 year, with the patients in the placebo group receiving olive oil. In patients with active disease at entry, it was possible to demonstrate a significant steroid-sparing effect, but fish oil failed to prevent clinical relapse in the group of patients who were enrolled in remission. Remarkably, LTB4 production in stimulated neutrophils was reduced by more than 50\%. Stenson et al. [16] carried out a randomised, double-blind, placebo-controlled crossover study with $5.4 \mathrm{~g}$ of n-3 PUFA as triacylglycerol (18 capsules daily), or olive oil as placebo, in 24 patients with active UC.

The patients received treatment for 4 months followed by 1 month of washout. The study demonstrated that fish oil was able to induce a significant gain in body weight, significantly improve histology score, and reduce LTB4 production in rectal dialysates by $60 \%$. No significant steroid-sparing effect was found, compared with placebo, and the improvement in endoscopy score did not reach significance $(p=0.06)$. Aslan et al. [15] carried out a similar placebo-controlled crossover trial in 17 patients with active UC, who received $4.2 \mathrm{~g}$ of n-3 PUFAs daily or corn oil as placebo for 3 months, followed by 2 months of wash-out. In $72 \%$ of patients, a steroid-sparing effect was seen, and in $56 \%$ the activity score of the disease improved significantly. Improvement of histology score did not reach statistical significance. Loeschke et al. [19] conducted a placebo-controlled trial on the prevention of UC relapse, in which 64 patients in remission were randomised to receive $5.1 \mathrm{~g}$ of $\mathrm{n}-3$ PUFAs as ethyl esters in fish oil or maize oil as placebo; ongoing treatment with 5-aminosalicylic acid (5-ASA) was 
allowed for 3 months. Interestingly, after 3 months of study the fish-oil group had fewer relapses than the placebo group $(p<0.02)$, but this beneficial effect was lost by the end of the study ( 2 years). This leads to speculation that fish oil and 5-ASA may have synergistic effects, and also that patient compliance in the fish-oil group decreased during the study and could have affected the clinical outcome. Lorenz-Meyer et al. [25] published data from a large, placebo-controlled trial in $204 \mathrm{CD}$ patients, who were included after an acute relapse of their disease, in which remission $(\mathrm{CDAI}<150)$ was obtained under steroid therapy. Patients were randomised to either n-3 PUFAs (5.1 g daily of fish oil as ethyl esters; $n=70)$, a carbohydrate-reduced diet (72 g/daily; $n=69)$, or placebo (corn oil; $n=65$ ) for 1 year. Low-dose prednisolone was given to all patients for the first 8 weeks of the trial and then discontinued. On an intent-to-treat analysis, none of the treatments were able to prevent clinical flare-up, but the diet poor in carbohydrates seemed to be effective at lowering the risk of relapse $(p<0.05)$, although it had the highest number of drop-outs (20 of 69 patients; $35 \%)$. Almallah et al. [21], in a pilot study, randomised $18 \mathrm{UC}$ patients with distal procto-colitis to $5.6 \mathrm{~g} /$ day EPA + DHA and placebo (sunflower oil) in a double-blind manner for 6 months. At the end of the study, the n-3 PUFAs group showed improvement in clinical activity, and sigmoidoscopic and histological scores, compared with the placebo group.

Possible explanations for these disparate results could be related to questionable study design, particularly in the cross-over study, in which a short wash-out period between active treatment and placebo may likely not have allowed a complete displacement of the extra n-3 PUFAs from cell membranes and could have interfered with the final results. Other possible factors may have been the use of different formulations and doses of n-3 PUFAs, poor patient compliance, incorrect administration regimens, and choosing olive oil or other oils rich in n-6 PUFAs with a strong biological activity, such as corn, maize and sunflower oil, as a placebo $[88,89]$.

Our group tested a new formulation of n-3 PUFAs, comprising a free fatty acid (FFA) mixture of $45 \%$ EPA and 20\% DHA in enteric-coated capsules, in 78 CD patients in remission but with high risk of relapse according to criteria defined by Brignola et al. [90]. The patients were randomly assigned to receive daily capsules containing either $2.7 \mathrm{~g}$ of $\mathrm{n}-3$ PUFAs or placebo ( $2.7 \mathrm{~g}$ capryl acid and capric acid). After 1 year of treatment, $59 \%$ of patients in the active group were still in remission, compared with only $26 \%$ in the placebo group $(p=0.006)$. Multivariate logistic regression analysis indicated that only n-3 PUFAs treatment reduced the likelihood of relapse (OR 4.2, 95\% CI: 1.6-10.7) [91]. Feagan et al. [92] tested a similar preparation of n-3 PUFAs in a large cohort of quiescent CD patients $(n>700)$ from the EPIC-1 and EPIC-2 trials, in order to prevent clinical relapse at 12 months. The endpoint was not reached and active treatment did not reduce relapse rate in CD patients between groups; even when taking the whole population for virtually all levels of remission, there was a delay of 30-50 days for the active treatment versus placebo group. It is difficult to explain the limited or absent clinical benefit of n-3 PUFAs in these two CD trials, in view of the strong biological rationale and positive data from previous studies.

The results were negative with comparable low relapse rates between active (31.6\%) and placebo $(35.7 \%)$ groups in the EPIC-1 trial, and the active (47.8\%) and placebo (48.8\%) groups in the EPIC-2 trial, after 1 year of follow up. A conceivable explanation for this failure is the lower sensitivity of the main clinical inclusion criteria in identifying patients at high risk of relapse in EPIC-1; in fact, the main inclusion criterion was "previous time in remission". The introduction of a reliable inflammatory marker of $C D$, such as $C$ reactive protein (CRP) at entry, could have better stratified patients with high risk of relapse. A significant group of patients may have been in stable remission and at low risk of relapse, possibly accounting for the low relapse rate in the placebo group after 1 year $(35.7 \%$ versus $65 \%$ in the Belluzzi study [91]).

EPIC-2 had a different design [90]. Relapse rate during follow-up after steroid treatment in the placebo group was $48.8 \%$ versus $47.8 \%$ in the active-treatment group, which is very low when compared to similar trials (up to $90 \%$ ) [93]. Fewer than $2 \%$ of patients had previous treatment with biologicals and only $7 \%$ were treated with immuno-modifying agents, suggesting they had very mild 
disease. It is unclear how many patients had genuine relapses requiring steroid treatment (CDAI at entry not shown). CRP levels after steroid tapering were not reported, so, again, a "real risk" of subsequent relapse is unknown.

Romano et al. [94] conducted a study of 38 children with quiescent CD, in which the addition of $1.8 \mathrm{~g}$ daily of enteric-coated n-3 PUFAs to 5-ASA treatment for 12 months appeared to be of benefit versus identical olive oil-containing placebo, in terms of number of clinical relapses $(p<0.001)$.

In a very interesting study, Uchiyama et al. [95] investigated the ability of a diet rich in n-3 PUFAs to rebalance the n-6/n-3 PUFAs ratio in patients with IBD. Because the 1:1 ratio target was too difficult to reach, the authors chose to aim for a ratio of 2:1 n-6/n-3 PUFAs. This was achieved using combined dietary changes (about $1700 \mathrm{mg} /$ day from EPA and DHA) plus supplementation of $7 \mathrm{~mL} /$ day of perilla oil (about $3400 \mathrm{mg} /$ day of ALA), and fatty acid composition of the erythrocyte membranes of 20 initial-onset IBD patients was measured. The authors found a significant increase in mean $n-3 / n-6$ PUFAs ratio after 12 months of intervention $(0.41 \pm 0.16$ versus $0.70 \pm 0.20 ; p<0.001)$. Furthermore, an additional 230 IBD patients (168 UC and 62 CD) after clinical remission underwent this n-3 PUFAs diet therapy plus perilla oil regimen. During the 18 months follow-up period, the $n 3-/ n-6$ PUFAs ratio in patients in the remission group $(n=145)$ was significantly higher than that of patients in the relapse group $(n=85)(0.65 \pm 0.28$ versus $0.53 \pm 0.18 ; p<0.001)$, confirming that alteration of cell membrane fatty acid composition after supplementation of n-3 PUFAs may have an influence on clinical activity of the disease.

Keeping in mind the importance of having a reliable marker of subclinical inflammation (an objective predictor of future relapse), we recently conducted a randomised, placebo-controlled trial in UC patients in clinical remission, but with high levels of faecal calprotectin (FC) $(\geq 150 \mu \mathrm{g} / \mathrm{g})$ at entry [96]. FC is a $36 \mathrm{kDa}$ calcium- and zinc-binding protein, comprising up to $60 \%$ of the total cytosolic protein in granulocytes, which is stable in faeces for up to 7 days and correlates well with faecal granulocyte excretion. FC is a useful marker of mucosal inflammation in IBD patients and is able to predict clinical relapse 3-6 months before it occurs [97].

We aimed to define the effectiveness of $2 \mathrm{~g} /$ daily of EPA as FFA in achieving a 100-point reduction of FC at 6 months from baseline (primary endpoint) and in maintaining clinical remission (secondary endpoint) versus placebo ( $2 \mathrm{~g} /$ daily of capric and caprylic acids). Sixty patients were enrolled, and the primary endpoint was achieved in $19 / 30(63.3 \%)$ versus $4 / 30(13.3 \%)$ of patients in the EPA-FFA and placebo groups, respectively (OR 12, 95\% CI: 3.12-46.24; $p<0.001$ ). The secondary endpoint was achieved in $23 / 30(76.7 \%)$ versus $15 / 30(50 \%)$ of patients in the EPA-FFA and placebo groups, respectively (OR 3.29, 95\% CI: 1.08-9.95; $p=0.035$ ). No serious adverse events were documented. EPA-FFA decreased FC levels and appears to be a safe and promising treatment for maintaining symptom-free remission in UC patients.

\section{Cochrane Reviews of n-3 PUFAs Treatment in IBD}

Cochrane reviews have assessed the role of n-3 PUFAs in IBD, both in UC (Table 1) and in CD (Table 2).

Turner et al. [27] systematically reviewed the efficacy of n-3 PUFAs for maintaining remission in UC, with primary outcome being relapse rate during the observation time. Only 3 studies were included in the analysis for a total patient number of 138; these studies had different n-3 PUFAs formulations and doses, and none used "enteric-coated" formulations. No evidence was found in favour of n-3 PUFAs, but a need for further studies using "enteric-coated" capsules was highlighted.

De Ley et al. [28] systematically reviewed the efficacy of n-3 PUFAs for induction of remission in UC. The primary outcome was proportion of patients achieving remission within 3 months after treatment. Six studies were included in the analysis for a total of 159 patients. The authors concluded that existing information is insufficient to make recommendations on the use of fish oil for UC in clinical practice, and more research is required. 
Table 1. Omega-3 fatty acids for maintenance and induction of remission in ulcerative colitis (UC).

\begin{tabular}{|c|c|c|c|c|c|c|c|c|}
\hline Study & Study Type-Duration & $\begin{array}{l}\text { Number of } \\
\text { Subjects-Inclusion Criteria }\end{array}$ & $\begin{array}{l}\text { Age } \\
\text { (years) }\end{array}$ & Supplementation & Placebo & $\begin{array}{l}\text { Concurrent } \\
\text { Medications }\end{array}$ & Outcomes & Results * \\
\hline \multirow{2}{*}{$\begin{array}{l}\text { Hawthorne, } \\
1992\end{array}$} & \multirow{2}{*}{$\begin{array}{l}\text { Double-blind, } \\
\text { placebo-controlled, } \\
\text { multicentre } 1 \text { year }\end{array}$} & \multirow{2}{*}{$\begin{array}{l}34 \text { adults: } 19 \text { (n-3 PUFAs arm) } \\
15 \text { (placebo arm) } \\
\text { In remission or while } \\
\text { recovering from relapse } \\
\text { No diet restrictions }\end{array}$} & \multirow[t]{2}{*}{$17-77$} & \multirow{2}{*}{$\begin{array}{l}\mathrm{n}-3 \text { PUFAs as } 10 \mathrm{~mL} \text { liquid } \\
\text { form twice daily of HiEPA } \\
(5 \mathrm{~g} / \text { day EPA }+1.2 \mathrm{~g} / \text { day } \\
\text { DHA, as triglyceride } \\
\text { concentrate) }\end{array}$} & \multirow{2}{*}{$\begin{array}{l}\text { Olive oil, } \\
10 \mathrm{~mL} \text { twice } \\
\text { daily }\end{array}$} & \multirow[t]{2}{*}{$\begin{array}{l}\text { 5-ASA, steroids } \\
(\leq 20 \mathrm{mg} / \text { day })\end{array}$} & $\begin{array}{l}\text { Relapse rates (active } \\
\text { symptoms and/or } \\
\text { inflamed rectal mucosa) }\end{array}$ & $\begin{array}{l}42 \% \text { vs. } 48 \% \\
(p=0.54)\end{array}$ \\
\hline & & & & & & & $\begin{array}{l}\text { Time to relapse (days), } \\
\text { median (IQR) }\end{array}$ & $\begin{array}{l}365(265-365) \text { vs. } 349 \\
(240-365)(p=N S)\end{array}$ \\
\hline \multirow{2}{*}{ Loeschke, 1996} & \multirow{2}{*}{$\begin{array}{l}\text { Double-blind, } \\
\text { placebo-controlled, } \\
\text { multicenter2 years }\end{array}$} & \multirow{2}{*}{$\begin{array}{l}64 \text { adults: } \\
33 \text { (n-3 PUFAs arm) } 31 \\
\text { (placebo arm) } \\
\text { In remission or low disease } \\
\text { activity (Gomez score }<8 \text { ) }\end{array}$} & \multirow{2}{*}{$\begin{array}{l}\text { n-3 arm: } 39 \pm 11^{\#} \\
\text { Placebo arm: } 40 \pm 13^{\#}\end{array}$} & \multirow{2}{*}{$\begin{array}{l}\text { Fish oil capsules, as } \\
\text { long-chain ethyl esters n-3 } \\
\text { PUFAs ( } 5.1 \text { g/day of total } \\
\text { n-3 PUFAs; dose of EPA } \\
\text { and DHA not reported) }\end{array}$} & \multirow[t]{2}{*}{ Maize oil } & \multirow{2}{*}{$\begin{array}{l}\text { 5-ASA } \\
\text { (discontinued } \\
3 \text { months after } \\
\text { randomisation) }\end{array}$} & $\begin{array}{l}\text { Relapse rate ( } \geq 4 \text {-point } \\
\text { increase in Gomez score) }\end{array}$ & $\begin{array}{l}58 \% \text { vs. } 55 \% ; \\
(p=0.81)\end{array}$ \\
\hline & & & & & & & $\begin{array}{l}\text { Mean clinical disease } \\
\text { activity score at the third } \\
\text { month of treatment }\end{array}$ & 2.2 vs. $4.4(p<0.05)$ \\
\hline \multirow[t]{2}{*}{ Mantzaris, 1996} & \multirow{2}{*}{$\begin{array}{l}\text { Double-blind, } \\
\text { placebo-controlled,single-centre } \\
1 \text { year }\end{array}$} & \multirow{2}{*}{$\begin{array}{l}50 \text { adults: } \\
27 \text { (n-3 PUFAs arm) } 23 \\
\text { (placebo arm) Clinical, } \\
\text { endoscopic remission } \\
\text { No diet restrictions }\end{array}$} & \multirow[t]{2}{*}{$17-65$} & \multirow{2}{*}{$\begin{array}{l}\mathrm{n}-3 \text { PUFAs as } 10 \mathrm{~mL} \text { liquid } \\
\text { form twice daily of } \\
\text { MaxEPA (3.2 g/day EPA + } \\
2.1 \mathrm{~g} / \text { day DHA, as } \\
\text { triacylglycerol) }\end{array}$} & \multirow{2}{*}{$\begin{array}{l}\text { Olive oil, } 10 \mathrm{~mL} \\
\text { twice } \\
\text { daily5-ASA }\end{array}$} & \multirow[t]{2}{*}{$\begin{array}{l}\text { 5-ASA } \\
\text { (3.6 g/day) }\end{array}$} & $\begin{array}{l}\text { Relapse rate (active } \\
\text { symptoms or endoscopic } \\
\text { signs of relapse) }\end{array}$ & $27 \%$ vs. $28 \%(p=1.0)$ \\
\hline & & & & & & & $\begin{array}{l}\text { Time to relapse (days), } \\
\text { median (IQR) }\end{array}$ & $\begin{array}{l}235(100-365) \text { vs. } 218 \\
(79-365)(p>0.1)\end{array}$ \\
\hline \multirow{2}{*}{ Aslan, 1992} & \multirow{2}{*}{$\begin{array}{l}\text { Double-blind, } \\
\text { placebo-controlled; } \\
\text { crossover design } 8 \text { months } \\
\text { ( } 3 \text { intervention period }+2 \\
\text { washout period })\end{array}$} & \multirow{2}{*}{$\begin{array}{l}17 \text { adults } \\
\text { Mild to moderate disease } \\
\text { activity }\end{array}$} & \multirow[t]{2}{*}{$31-74$} & \multirow{2}{*}{$\begin{array}{l}\text { MaxEPA capsules ( } 2.7 \\
\text { g/day EPA + } 1.8 \text { g/day } \\
\text { DHA) }\end{array}$} & \multirow{2}{*}{$\begin{array}{l}\text { Corn oil }(10.3 \mathrm{~g} \\
\text { OA }+2.1 \mathrm{~g} \mathrm{PA}+ \\
1.8 \mathrm{~g} \mathrm{LA})\end{array}$} & \multirow{2}{*}{$\begin{array}{l}\text { Oral steroids } \\
\text { (<20 mg/day }) \\
\text { or SASP }\end{array}$} & $\begin{array}{l}\text { Clinical response } \\
\text { (decrease in DAI score } \\
\text { after MaxEPA) }\end{array}$ & $56 \%$ vs. $4 \% p<0.05$ \\
\hline & & & & & & & $\begin{array}{l}\text { Steroid-sparing effects } \\
\text { during MaxEPA therapy }\end{array}$ & $\begin{array}{l}72 \% \text { reduced } \\
\text { anti-inflammatory } \\
\text { dosage and/or } \\
\text { eliminated steroids } \\
\text { ( } p \text { value not reported) } \\
\end{array}$ \\
\hline \multirow[t]{2}{*}{ Stenson, 1992} & \multirow[t]{2}{*}{$\begin{array}{l}\text { Double-blind, } \\
\text { placebo-controlled, } \\
\text { randomised, multicentre; } \\
\text { crossover design } 5 \text { months } \\
\text { (4 intervention period + } 1 \\
\text { washout period) }\end{array}$} & \multirow[t]{2}{*}{$\begin{array}{l}24 \text { adults } \\
\text { Active disease }\end{array}$} & \multirow[t]{2}{*}{$25-62$} & \multirow[t]{2}{*}{$\begin{array}{l}\text { MaxEPA capsules } \\
(3.24 \mathrm{~g} / \text { day EPA + } \\
2.16 \mathrm{~g} / \text { day DHA, as } \\
\text { triacylglycerol })\end{array}$} & \multirow[t]{2}{*}{$\begin{array}{l}\text { Vegetable oil } \\
(12.36 \mathrm{~g} \mathrm{OA}+ \\
2.52 \mathrm{~g} \mathrm{PA}+2.16 \\
\text { g LA) }\end{array}$} & \multirow[t]{2}{*}{$\begin{array}{l}\text { Prednisone, } \\
\text { SASP }\end{array}$} & $\begin{array}{l}\text { Endoscopic score } \\
\text { improvement }\end{array}$ & $\begin{array}{l}\mathrm{n}-3 \text { PUFAs group: } \\
\text { mean decrease of } \\
-2.09(95 \% \text { CI: }-4.63 \\
\text { to } 0.45 ; p=0.06) \\
\text { Placebo group: mean } \\
\text { decrease of }-0.17 \\
(95 \% \text { CI: }-1.75 \text { to } 1.41 ; \\
p=0.10)\end{array}$ \\
\hline & & & & & & & Steroid-sparing effect & NS in both groups \\
\hline
\end{tabular}


Table 1. Cont.

\begin{tabular}{|c|c|c|c|c|c|c|c|c|}
\hline Study & Study Type-Duration & $\begin{array}{l}\text { Number of } \\
\text { Subjects-Inclusion Criteria }\end{array}$ & $\begin{array}{l}\text { Age } \\
\text { (years) }\end{array}$ & Supplementation & Placebo & $\begin{array}{l}\text { Concurrent } \\
\text { Medications }\end{array}$ & Outcomes & Results * \\
\hline Stack, 1997 & $\begin{array}{l}\text { Double-blind, controlled, } \\
\text { randomised; parallel design } \\
4 \text { months }\end{array}$ & $\begin{array}{l}66 \text { adults: } \\
14 \text { (n-3 PUFAs group) } \\
13 \text { (n-6 PUFAs group) } \\
13 \text { (n-3 and n-6 PUFAs group) } \\
13 \text { (placebo group) }\end{array}$ & & $\begin{array}{l}\mathrm{n}-3 \text { PUFAs group: } \\
1.5 \mathrm{~g} \text { EPA }\end{array}$ & $\begin{array}{l}\mathrm{n}-6 \text { PUFAs } \\
\text { group: } 2.1 \mathrm{~g} \\
\text { GLA Placebo } \\
\text { group: } \\
\text { sunflower oil }\end{array}$ & Steroids & Steroid-sparing effect & $\begin{array}{l}\text { No evidence with n-3 } \\
\text { or n-6 PUFAs } \\
\text { compared to placebo } \\
\text { either alone or in } \\
\text { combination }(p \text { value } \\
\text { not reported) }\end{array}$ \\
\hline \multirow{3}{*}{ Almallah, 1998} & \multirow{3}{*}{$\begin{array}{l}\text { Double-blind, } \\
\text { placebo-controlled, } \\
\text { randomised, single-centre; } \\
\text { parallel design } 6 \text { months }\end{array}$} & \multirow{3}{*}{$\begin{array}{l}18 \text { adults: } \\
9 \text { (n-3 PUFAs arm) } \\
9 \text { (placebo arm) } \\
\text { Low disease activity (Gomez } \\
\text { score }<8 \text { ) } \\
\text { On Western diet }\end{array}$} & \multirow{3}{*}{$\begin{array}{l}\text { n-3 PUFAs arm: } 29-64 \\
\text { Placebo arm: } 32-72\end{array}$} & \multirow{3}{*}{$\begin{array}{l}\mathrm{n}-3 \text { PUFAs as } 15 \mathrm{~mL} \\
\text { fish-oil extract (3.2 g/day } \\
\text { EPA + } 2.4 \mathrm{~g} / \text { day DHA) }\end{array}$} & \multirow{3}{*}{$\begin{array}{l}\text { Sunflower oil, } \\
15 \mathrm{ml}(2.6 \mathrm{~g} / \text { day } \\
\text { oleic acid }+ \\
7.9 \mathrm{~g} / \text { day } \\
\text { linoleic acid })\end{array}$} & \multirow{3}{*}{ SASP or 5-ASA } & Clinical response & $p<0.05$ \\
\hline & & & & & & & $\begin{array}{l}\text { Endoscopic score } \\
\text { improvement (RSS) }\end{array}$ & $\begin{array}{l}p=0.013(\mathrm{n}-3 \text { PUFAs } \\
\text { arm) } p=\mathrm{NS} \\
\text { (placebo arm) }\end{array}$ \\
\hline & & & & & & & $\begin{array}{l}\text { Histological score } \\
\text { improvement }\end{array}$ & $p=0.016$ \\
\hline \multirow[t]{2}{*}{ Dichi, 2000} & \multirow{2}{*}{$\begin{array}{l}\text { Randomised, single-centre; } \\
\text { crossover design } 6 \text { months } \\
(2 \text { intervention period }+2 \\
\text { washout period }+2 \text { crossover } \\
\text { intervention period })\end{array}$} & \multirow{2}{*}{$\begin{array}{l}10 \text { adults } \\
\text { Mild to moderate } \\
\text { disease activity }\end{array}$} & \multirow[t]{2}{*}{$33-65$} & \multirow{2}{*}{$\begin{array}{l}5.4 \mathrm{~g} / \text { day } \mathrm{n}-3 \text { PUFAs } \\
\text { fish-oil capsule, as fatty } \\
\text { acids ( } 180 \mathrm{mg} \text { EPA + } \\
120 \mathrm{mg} \text { DHA in } \\
\text { each capsule) }\end{array}$} & \multirow[t]{2}{*}{$2.2 \mathrm{~g} /$ day SASP } & & $\begin{array}{l}\text { Laboratory blood } \\
\text { parameters }\end{array}$ & $\begin{array}{l}\uparrow \text { of CRP, ERS, PLT } \\
\text { during n-3 PUFAs } \\
\text { treatment }(p<0.01) \\
\text { Changes during SASP } \\
\text { therapy: } p=\text { NS }\end{array}$ \\
\hline & & & & & & & $\begin{array}{l}\text { Improvement in } \\
\text { sigmoidoscopy score }\end{array}$ & $\begin{array}{l}\text { At entry, mean } 9.6 \\
\text { (SD } \pm 2.8) \text { After } \mathrm{n}-3 \\
\text { PUFAs treatment, } \\
\text { mean } 5.0(\mathrm{SD} \pm 5.7) \\
p<0.01\end{array}$ \\
\hline \multirow[t]{2}{*}{ Varghese, 2000} & \multirow[t]{2}{*}{$\begin{array}{l}\text { Double-blind, randomised; } \\
\text { parallel design } 6 \text { months }\end{array}$} & \multirow{2}{*}{$\begin{array}{l}51 \text { adults: } \\
21 \text { (n-3 PUFAs arm) } \\
30 \text { (placebo arm) } \\
\text { Active and extensive disease }\end{array}$} & & \multirow[t]{2}{*}{ Fish oil $5.6 \mathrm{mg} /$ day } & \multirow[t]{2}{*}{ Sunflower oil } & & $\begin{array}{l}\text { Clinical scores } \\
\text { improvement }\end{array}$ & $\begin{array}{l}\mathrm{n}-3 \text { PUFAs arm: } \\
p=0.001 \\
\text { (no quantitative data } \\
\text { presented) }\end{array}$ \\
\hline & & & & & & & $\begin{array}{l}\text { Endoscopic score } \\
\text { improvement }\end{array}$ & $\begin{array}{l}\mathrm{n}-3 \text { PUFAs arm: } \\
p=0.054 \text { (no } \\
\text { quantitative data } \\
\text { presented) }\end{array}$ \\
\hline
\end{tabular}

* Expressed as results in the n-3 PUFAs arm versus results in the placebo arm in studies investigating omega-3 fatty acids for maintenance of remission in UC. \# Age expressed as mean \pm SD. 5-ASA, 5-aminosalicylic acid or mesalazine; CI, confidence interval; CRP, C reactive protein; DAI, disease activity index; DHA, docosahexanoic acid; EPA, eicosapentanoic acid; ERS, erythrocyte sedimentation rate; GLA, gamma linolenic acid; IQR, interquartile range; LA, linoleic acid; NS, not significant; OA, oleic acid; PA, palmitic acid; PLT, platelet; PUFA, polyunsaturated fatty acid; RSS, rectosigmoidoscopy; SASP, sulfasalazine; SD, standard deviation; UC, ulcerative colitis. 
Table 2. Omega-3 fatty acids for maintenance of remission in Crohn's disease (CD).

\begin{tabular}{|c|c|c|c|c|c|c|c|c|}
\hline Author & Study Type-Duration & $\begin{array}{l}\text { Number of } \\
\text { Subjects-Inclusion Criteria }\end{array}$ & $\begin{array}{l}\text { Age } \\
\text { (years) }\end{array}$ & Supplementation & Placebo & $\begin{array}{l}\text { Concurrent } \\
\text { Medications }\end{array}$ & Outcomes & $\begin{array}{l}\text { Results } \\
\text { (n-3 PUFAs Arm vs. } \\
\text { Placebo arm) }\end{array}$ \\
\hline \multirow{3}{*}{ Belluzzi, 1996} & \multirow{3}{*}{$\begin{array}{l}\text { Double-blind, } \\
\text { placebo-controlled, } \\
\text { single-centre } 1 \text { year }\end{array}$} & \multirow{3}{*}{$\begin{array}{l}78 \text { adults: } \\
39(\mathrm{n}-3 \text { PUFAs arm) } 39 \\
\text { (placebo arm) } \\
\text { CDAI }<150 \text { at baseline, but at } \\
\text { high risk of relapse } \\
\text { No diet restrictions }\end{array}$} & \multirow{3}{*}{$18-67$} & \multirow{3}{*}{$\begin{array}{l}\text { Enteric-coated, } \\
\text { time-released, fish-oil } \\
\text { capsule ( } 1.8 \mathrm{~g} / \text { day EPA + } \\
0.9 \mathrm{~g} / \text { day DHA, as FFAs) }\end{array}$} & \multirow{3}{*}{$\begin{array}{l}\text { Capsules } 500 \\
\text { mg Miglyol } 182 \\
\text { (caprylic acid }+ \\
\text { capric acid) }\end{array}$} & \multirow{3}{*}{ None } & $\begin{array}{l}\text { Relapse rate }(\mathrm{CDAI}>150 \\
\text { or } \geq 100 \text { points increase in } \\
\text { CDAI from baseline) }\end{array}$ & $\begin{array}{l}11.28 \% \text { vs. } 27.69 \% \\
(p<0.001)\end{array}$ \\
\hline & & & & & & & Time to first relapse & $\begin{array}{l}>1 \text { year vs. } 4 \text { months } \\
\text { (log rank test } 0.006)\end{array}$ \\
\hline & & & & & & & Adverse events & 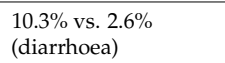 \\
\hline \multirow{3}{*}{$\begin{array}{l}\text { Lorenz-Meyer, } \\
1996\end{array}$} & \multirow{3}{*}{$\begin{array}{l}\text { Double-blind, } \\
\text { placebo-controlled, } \\
\text { multicenter } 1 \text { year }\end{array}$} & \multirow{3}{*}{$\begin{array}{l}135 \text { adults: } \\
70 \text { (n-3 PUFAs arm) } \\
65 \text { (placebo arm) CDAI }<150 \\
\text { at baseline (steroid-induced } \\
\text { remission after an acute } \\
\text { relapse) } \\
\text { Diet low in AA and rich } \\
\text { in fibre }\end{array}$} & \multirow{3}{*}{$17-65$} & \multirow{3}{*}{$\begin{array}{l}\text { Non-enteric-coated } \mathrm{n}-3 \\
\text { PUFAs capsules }(3.3 \\
\text { g/day EPA }+1.8 \mathrm{~g} / \text { day } \\
\text { DHA, as ethyl ester) }\end{array}$} & \multirow{3}{*}{ Corn oil } & \multirow{3}{*}{$\begin{array}{l}\text { Low-dose } \\
\text { prednisolone in } \\
\text { the first } 8 \text { weeks }\end{array}$} & $\begin{array}{l}\text { Relapse rate }(\mathrm{CDAI}>200 \\
\text { or } \geq 60 \text { points increase in } \\
\text { CDAI from baseline, plus } \\
\geq 2 \mathrm{SD} \text { above normal } \\
\text { mean CRP increase }\end{array}$ & $\begin{array}{l}57.00 \% \text { vs. } 36.55 \% \\
(p=0.84)\end{array}$ \\
\hline & & & & & & & Time to first relapse & $\begin{array}{l}159 \text { days vs. } 133 \text { days } \\
\text { (NS) }\end{array}$ \\
\hline & & & & & & & Adverse events & $\begin{array}{l}1.4 \% \text { vs. } 1.5 \% \\
\text { (diarrhoea) } \\
14.3 \% \text { vs. } 3.1 \% \\
\text { (halitosis) } \\
14.3 \% \text { vs. } 3.1 \% \text { (upper } \\
\text { GI symptoms) }\end{array}$ \\
\hline \multirow[t]{2}{*}{ Belluzzi, 1997} & \multirow[t]{2}{*}{$\begin{array}{l}\text { Double-blind, } \\
\text { placebo-controlled, } \\
\text { single-centre } 1 \text { year }\end{array}$} & \multirow{2}{*}{$\begin{array}{l}50 \text { adults; } \\
26 \text { (n-3 PUFAs arm) } 24 \\
\text { (placebo arm) } \\
\text { CDAI <150 one month after } \\
\text { ileal resection }\end{array}$} & & \multirow{2}{*}{$\begin{array}{l}\text { Enteric-coated, } \\
\text { time-released, fish-oil } \\
\text { capsule ( } 1.8 \mathrm{~g} / \text { day EPA + } \\
0.9 \mathrm{~g} / \text { day DHA, as FFAs) }\end{array}$} & \multirow{2}{*}{$\begin{array}{l}\text { Capsules } 500 \\
\text { mg Miglyol } 182 \\
\text { (caprylic acid }+ \\
\text { capric acid) }\end{array}$} & \multirow[t]{2}{*}{ None } & $\begin{array}{l}\text { Clinical relapse rate } \\
(\text { CDAI }>150 \text { with an } \\
\text { increase of }>50 \text { points } \\
\text { from baseline) } \\
\text { Histological relapse }\end{array}$ & $\begin{array}{l}2.8 \% \text { vs. } 5.21 \% \\
(p=0.24) 9.34 \% \text { vs. } \\
15.62 \% \\
(p=0.09)\end{array}$ \\
\hline & & & & & & & Adverse events & $\begin{array}{l}\text { None (personal } \\
\text { communication) }\end{array}$ \\
\hline \multirow[t]{3}{*}{ Romano, 2005} & \multirow{3}{*}{$\begin{array}{l}\text { Double-blind, } \\
\text { placebo-controlled, } \\
\text { multicenter } 1 \text { year }\end{array}$} & \multirow{3}{*}{$\begin{array}{l}38 \text { children: } \\
18 \text { ( } \mathrm{n}-3 \text { PUFAs arm) } 20 \\
\text { (placebo arm) } \\
\text { PCDAI }<20 \text { for at least } \\
2 \text { months at baseline }\end{array}$} & \multirow[t]{3}{*}{$5-16$} & \multirow{3}{*}{$\begin{array}{l}\text { Enteric-coated n-3 PUFAs } \\
\text { capsules }(1.2 \mathrm{~g} / \text { day EPA }+ \\
0.6 \mathrm{~g} / \text { day DHA, as } \\
\text { triglycerides })\end{array}$} & \multirow{3}{*}{ Olive oil } & \multirow{3}{*}{$\begin{array}{l}\text { Time-dependent } \\
5 \text {-ASA } \\
(50 \mathrm{mg} / \mathrm{kg} / \text { day })\end{array}$} & Relapse rate $(\mathrm{PCDAI}>20)$ & $\begin{array}{l}\begin{array}{l}61 \% \text { vs. } 95 \% \\
(p<0.001)\end{array} \\
\end{array}$ \\
\hline & & & & & & & Time to first relapse & 8 months vs. 1 month \\
\hline & & & & & & & Adverse events & None \\
\hline
\end{tabular}


Table 2. Cont.

\begin{tabular}{|c|c|c|c|c|c|c|c|c|}
\hline Author & Study Type-Duration & $\begin{array}{l}\text { Number of } \\
\text { Subjects-Inclusion Criteria }\end{array}$ & $\begin{array}{l}\text { Age } \\
\text { (years) }\end{array}$ & Supplementation & Placebo & $\begin{array}{l}\text { Concurrent } \\
\text { Medications }\end{array}$ & Outcomes & $\begin{array}{l}\text { Results } \\
\text { (n-3 PUFAs Arm vs. } \\
\text { Placebo arm) }\end{array}$ \\
\hline \multirow{4}{*}{$\begin{array}{l}\text { Feagan, } 2008 \\
\text { (EPIC-1) }\end{array}$} & \multirow{4}{*}{$\begin{array}{l}\text { Double-blind, } \\
\text { placebo-controlled, } \\
\text { multicenter } 52 \text { weeks }\end{array}$} & \multirow{4}{*}{$\begin{array}{l}363 \text { adults: } \\
183 \text { (n-3 PUFAs arm) } 180 \\
\text { (placebo arm) } \\
\text { CDAI }<150 \text { for at least } 3 \\
\text { months but }<12 \text { months at } \\
\text { baseline }\end{array}$} & \multirow{4}{*}{ 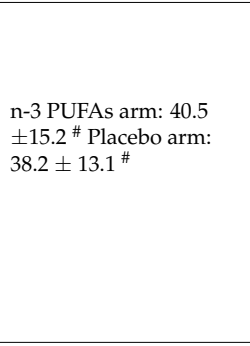 } & \multirow{4}{*}{$\begin{array}{l}\text { Enteric-coated, } \\
\text { time-released n-3 PUFAs } \\
\text { capsules }(2.2 \mathrm{~g} / \text { day EPA + } \\
0.8 \mathrm{~g} / \text { day DHA, as FFAs) * }\end{array}$} & \multirow{4}{*}{$\begin{array}{l}4 \mathrm{~g} / \text { day } \\
\text { medium-chain } \\
\text { triglyceride oil }\end{array}$} & \multirow{4}{*}{ None } & $\begin{array}{l}\text { Relapse rate (CDAI }>150 \\
\text { or }>70 \text { points increase } \\
\text { from baseline) }\end{array}$ & $\begin{array}{l}31.6 \% \text { vs. } 35.7 \% \mathrm{HR} \\
0.82,95 \% \mathrm{CI} \\
0.51-1.19(p=0.30)\end{array}$ \\
\hline & & & & & & & Adverse events & $\begin{array}{l}18.7 \% \text { vs. } 11.4 \% \\
\text { (diarrhoea) } 1 \% \text { vs. } \\
0.5 \% \text { (dysgeusia) } 9.1 \% \\
\text { vs. } 2.2 \% \text { (nausea) } \\
14.4 \% \text { vs. } 6.5 \% \text { (all } \\
\text { upper GI symptoms) }\end{array}$ \\
\hline & & & & & & & Change in mean CDAI & NS \\
\hline & & & & & & & Change in SF-36 scores & NS \\
\hline \multirow{4}{*}{$\begin{array}{l}\text { Feagan, } 2008 \\
\text { (EPIC-2) }\end{array}$} & \multirow{4}{*}{$\begin{array}{l}\text { Double-blind, } \\
\text { placebo-controlled, } \\
\text { Multicenter } 58 \text { weeks }\end{array}$} & \multirow{4}{*}{$\begin{array}{l}375 \text { adults: } 187 \text { (n-3 PUFAs } \\
\text { arm) } 188 \text { (placebo arm) CDAI } \\
\text { < } 150 \text { atter } 8 \text { weeks of } \\
\text { steroid-induced remission }\end{array}$} & \multirow{4}{*}{$\begin{array}{l}\text { n-3 PUFAs arm: } 38.5 \\
\pm 13.8^{\#} \text { Placebo arm: } 40 \\
\pm 13.6^{\#}\end{array}$} & \multirow{4}{*}{$\begin{array}{l}\text { Enteric-coated, } \\
\text { time-released } \mathrm{n}-3 \text { PUFAs } \\
\text { capsules }(2.2 \mathrm{~g} / \text { day EPA }+ \\
0.8 \mathrm{~g} / \text { day DHA as FFAs })^{*}\end{array}$} & \multirow{4}{*}{$\begin{array}{l}\text { Four } 1 \mathrm{~g} \text { of } \\
\text { medium-chain } \\
\text { triglyceride oil }\end{array}$} & \multirow{4}{*}{$\begin{array}{l}\text { Prednisone } 20 \\
\mathrm{mg} / \text { day or } \\
\text { budesonide } \\
6 \mathrm{mg} / \text { day } \\
\text { tapered off over } \\
8 \text { weeks from } \\
\text { randomisation }\end{array}$} & $\begin{array}{l}\text { Relapse rate }(\mathrm{CDAI}>150 \\
\text { or }>70 \text { points increase } \\
\text { from baseline) }\end{array}$ & $\begin{array}{l}47.8 \% \text { vs. } 48.8 \% \mathrm{HR} \\
0.90,95 \% \text { CI: } \\
0.67-1.21(p=0.48) \\
\end{array}$ \\
\hline & & & & & & & Adverse events & $\begin{array}{l}23.2 \% \text { vs. } 19.7 \% \\
\text { (diarrhoea) } 5.3 \% \text { vs. } \\
1.1 \% \text { (dysgeusia) } \\
15.9 \% \text { vs. } 10.1 \% \\
\text { (nausea) } 35.4 \% \text { vs. } \\
23.9 \% \text { (all upper GI } \\
\text { symptoms) }\end{array}$ \\
\hline & & & & & & & Change in mean CDAI & NS \\
\hline & & & & & & & Change in SF-36 scores & NS \\
\hline
\end{tabular}

* Dose of the study drug increased by $1 \mathrm{~g}$ every week to improve tolerability, till the final dose (2 capsules twice daily). ${ }^{*}$ Age expressed as mean \pm SD. 5-ASA, 5-aminosalicylic acid or mesalazine; AA, arachidonic acid; CDAI, Crohn's disease activity index; CI, confidence interval; CRP, C reactive protein; DHA, docosahexanoic acid; EPA, eicosapentanoic acid; FFA, free fatty acid; GI, gastrointestinal; HR, hazard ratio; PCDAI, Pediatric Crohn's disease activity index; PUFA, polyunsatured fatty acid; NS, not significant; SD, standard deviation; SF-36, 36-Item Short-Form Health Survey. 
It is clear from these two Cochrane reviews in UC that the low number and poor quality of current studies in this field make it impossible to suggest guidelines on the use of n-3 PUFAs for treating patients with UC. As the authors stated in their conclusions, more large, well-designed studies, possibly including better active treatment and placebo preparations, are needed to address this important question.

Lev-Tzion et al. [13] systematically reviewed the efficacy of n-3 PUFAs for maintaining remission in CD. The primary outcome was relapse rate during the observation time, and six studies, for a total of 1039 patients, were included. The authors' conclusions were based on the results of Feagan et al. [92]. Evidence from two large, high-quality studies suggests that n-3 PUFAs are probably ineffective for maintenance of remission in CD.

In our opinion, it is inappropriate to dismiss the potential of n-3 PUFAs to prevent relapse in CD at high risk of relapse on the basis of the EPIC studies; indeed, Turner et al. in a Cochrane systematic review [14] analysing the same six studies in CD (1039 patients) did not rule out a possible beneficial effect of n-3 PUFAs in these patients.

\subsection{New Formulations and Bioavailability of $n-3$ PUFAs}

The major natural dietary source of long-chain n-3 PUFAs is cold water-dwelling, oily fish; such fish can be consumed safely in large quantities.

The need to administer high doses of n-3 PUFAs to achieve a therapeutic benefit has encouraged the development of new formulations. One of the main concerns when increasing the daily dose of $n-3$ PUFAs is patient compliance. The commercially available marine fish-oil preparations are mainly in the form of fatty acid triglycerides or ethyl esters. It is clear that although fish oil has no serious toxicity, minor adverse events (AEs) such as dysgeusia, flatulence, pyrosis, halitosis, belching, and abdominal discomfort are common and may limit compliance [98]. Enteric coating of the fish-oil capsules may help to minimise upper gastrointestinal effects. There are conflicting data on the comparative bioavailability and AE profiles of n-3 PUFAs conjugated to a glycerol chain, as an ethyl ester conjugate and as FFA [99], but direct comparison of the three forms suggests that bioavailability is highest with the FFA conjugate and lowest with the ethyl ester conjugate [100].

Oral administration of fish oil containing the two main bioactive components, C20:5n3 EPA and C22:6n3 DHA, can replace C18:2n6 LA and C20:4n6 AA in a time- and dose-dependent manner in plasma and cellular phospholipid membranes [45]. Plasma n-3 PUFAs level is the easiest marker of EPA and DHA intake to use when measuring compliance with various fish-oil preparations. However, it is established that the plasma phospholipid fatty acid profile may change within a period of hours, depending on the type and timing of food intake [38]. Therefore, analysis of red blood cell (RBC) membrane n-3 PUFAs content is accepted as a more reliable measure [38]. The relatively long half-life of the RBC (120 days) provides a more stable measure of the incorporation of fatty acids into cellular phospholipid membranes [101]. The omega-3 index (the combined percentage content of EPA, DPA and DHA in RBC phospholipid membranes) can reach $\geq 8 \%$ with achievable and well tolerated $n-3$ PUFAs intake [38].

We recently carried out a pharmacokinetic study in a group of patients with IBD in stable remission and healthy volunteers, and showed that daily intake of $2 \mathrm{~g}$ EPA-FFA induces an efficient and consistent EPA incorporation into plasma phospholipids and RCB membranes. EPA-FFA is quickly converted into DHA via DPA, so that EPA can be considered as the "universal donor" of n-3 PUFAs. Treatment was very well tolerated, with only a few minor side effects [102].

There is no doubt that great interest exists in the development of a new formulation that can increase the bioavailability and long-term tolerability of n-3 PUFAs preparations.

TP-252 EPA-FFA is a new n-3 PUFAs enteric-coated powder preparation, in which two molecules of EPA in FFA form are bound to a scaffold made from mineral amino-acid. This preparation easily dissociates in aqueous media, displaying a favourable safety profile [103]. Maki et al. [104] reported on the superiority of MAT9001, a new n-3 PUFAs engineered-matrix, delayed-release $1 \mathrm{~g}$ capsule 
formulation to deliver EPA and DHA, versus ethyl-ester EPA in dyslipidaemia. A newly developed n-3 PUFAs hard tablet has shown faster absorption compared to traditional soft gelatine capsules, after testing for bioavailability of EPA and DHA [105]. Proposed reasons for the faster uptake of this preparation are the possibility of more rapid passage through the gastrointestinal system and improved solubility of fatty acids, reducing the dependence on emulsifying bile during absorption.

\section{Conclusions and Future Perspectives}

It is now clear that the Western diet often suffers from an important disequilibrium in the n-6/n-3 PUFAs ratio, reaching up to 20:1 in some cases, and that such an imbalance represents a powerful pro-inflammatory stimulus that can affect the onset of many underlying conditions, including IBD.

Since the 1980s, this disequilibrium has been corrected in patients with IBD by adding low-level n-3 PUFAs preparations to ongoing therapy. Subsequently, it was understood that positive results can be obtained by administering n-3 PUFAs pharmacologically, and hence increasingly sophisticated, high-concentration, and specific delivery technologies have been developed for this purpose. The discovery of n-3 PUFAs-derived anti-inflammatory molecules coined SPMs that can counteract and regulate pro-inflammatory chemical mediators, increase anti-inflammatory cytokines, and stimulate wound healing tissue regeneration and re-epithelialisation may offer a fascinating new complementary approach to IBD treatment. n-3 PUFAs therapeutic supplementation should be considered as an immune-resolving approach that can complement existing immunosuppressive therapies (Figure 3).

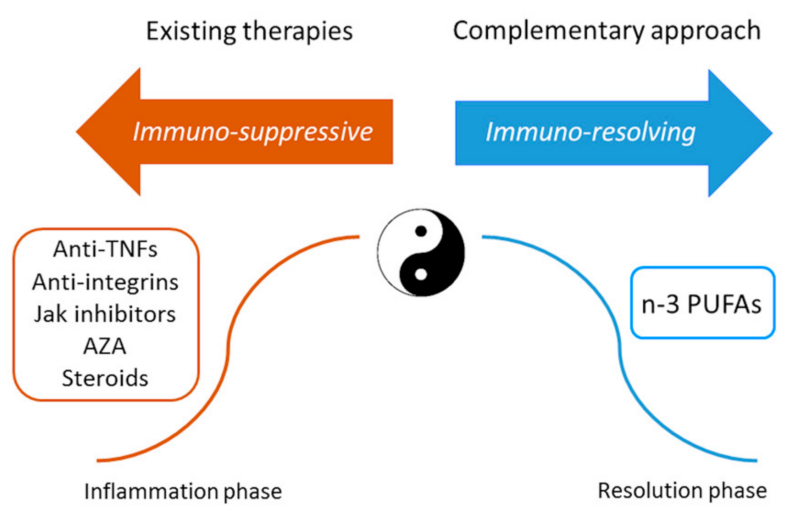

Figure 3. The immuno-suppressive and immuno-resolving approaches of inflammatory bowel disease treatment. AZA, azathioprine; PUFA, polyunsaturated fatty acid; TNF, tumour necrosis factor.

However, there remains a lack of well-designed clinical trials that include IBD patients selected using reliable criteria, such as new inflammatory disease markers (i.e., faecal calprotectin), to confirm the intriguing findings that are emerging from smaller studies, and, in particular, to confirm the possibility not only of preventing the recurrence of IBD but also of delaying or blocking its onset with the aid of a diet containing a balanced ratio of n-6/n-3 PUFAs.

Acknowledgments: We would like to thank James Reed of Blue Heeler Limited for language editing.

Author Contributions: Eleonora Scaioli, Elisa Liverani and Andrea Belluzzi wrote the paper.

Conflicts of Interest: The authors declare no conflict of interest. Andrea Belluzzi received travel grant from SLA Pharma. 


\section{Abbreviations}

\begin{tabular}{|c|c|}
\hline 5-ASA & 5-aminosalicylic acid \\
\hline AA & Arachidonic acid \\
\hline $\mathrm{AE}$ & Adverse event \\
\hline ALA & $\alpha$-linolenic acid \\
\hline $\mathrm{CD}$ & Crohn's disease \\
\hline CI & Confidence interval \\
\hline COX & Cyclooxygenase \\
\hline CDAI & Crohn's Disease Activity Index \\
\hline CRP & $\mathrm{C}$ reactive protein \\
\hline DHA & Docosahexaenoic acid \\
\hline DPA & Docosapentaenoic acid \\
\hline EET & Epoxyeicosatrienoic acid \\
\hline ELOVL & Elongase of very long chain fatty acids \\
\hline EPA & Eicosapentaenoic acid \\
\hline EPIC & $\begin{array}{l}\text { European Prospective Investigation into Cancer and } \\
\text { Nutrition }\end{array}$ \\
\hline FADS & Fatty acid desaturase \\
\hline FC & Faecal calprotectin \\
\hline FFA & Free fatty acid \\
\hline GLA & n-6 gamma linolenic acid \\
\hline HETEs & Hydroxyeicosatetraenoic acid \\
\hline HR & Hazard ratio \\
\hline IBD & Inflammatory bowel disease \\
\hline IL & Interleukin \\
\hline LA & Linoleic acid \\
\hline LOX & Lipoxygenase \\
\hline LT & Leukotriene \\
\hline LX & Lipoxin \\
\hline MAPK & Mitogen-activated protein kinase \\
\hline$N F k \beta$ & Nuclear factor $\mathrm{kB}$ \\
\hline NLRs & NOD-like receptors \\
\hline NLRP3 & NOD-like receptor protein 3 \\
\hline $\mathrm{NO}$ & Nitric oxide \\
\hline NOD2 & Nucleotide-binding oligomerisation domain 2 \\
\hline NOS & Nitric oxide synthase \\
\hline $\mathrm{OA}$ & Oleic acid \\
\hline OR & Odds ratio \\
\hline PG & Prostaglandin \\
\hline PPAR- $\gamma$ & Peroxisome proliferator-activated receptor $\gamma$ \\
\hline PUFAs & Polyunsaturated fatty acids \\
\hline RBC & Red blood cell \\
\hline SNPs & Single nucleotide polymorphisms \\
\hline SPM & Specialised pro-resolving mediator \\
\hline TLRs & Toll-like receptors \\
\hline $\mathrm{TNF} \alpha$ & Tumor necrosis factor $\alpha$ \\
\hline $\mathrm{TX}$ & Thromboxane \\
\hline $\mathrm{UC}$ & Ulcerative colitis \\
\hline VCAM-1 & Vascular cell adhesion molecule 1 \\
\hline
\end{tabular}




\section{References}

1. Blasbalg, T.L.; Hibbeln, J.R.; Ramsden, C.E.; Majchrzak, S.F.; Rawlings, R.R. Changes in consumption of omega-3 and omega-6 fatty acids in the United States during the 20th century. Am. J. Clin. Nutr. 2011, 93, 950-962. [CrossRef] [PubMed]

2. Molodecky, N.A.; Soon, I.S.; Rabi, D.M.; Ghali, W.A.; Ferris, M.; Chernoff, G.; Benchimol, E.I.; Panaccione, R.; Ghosh, S.; Barkema, H.W.; et al. Increasing incidence and prevalence of the inflammatory bowel diseases with time, based on systematic review. Gastroenterology 2012, 142, 46-54. [CrossRef] [PubMed]

3. De Silva, P.S.; Olsen, A.; Christensen, J.; Schmidt, E.B.; Overvaad, K.; Tjonneland, A.; Hart, A.R. An association between dietary arachidonic acid, measured in adipose tissue, and ulcerative colitis. Gastroenterology 2010, 139, 1912-1917. [CrossRef] [PubMed]

4. IBD in EPIC Study Investigators; Tjonneland, A.; Overvad, K.; Bergmann, M.M.; Nagel, G.; Linseisen, J.; Hallmans, G.; Palmqvist, R.; Sjodin, H.; Hagglund, G.; et al. Linoleic acid, a dietary n-6 polyunsaturated fatty acid, and the aetiology of ulcerative colitis: A nested case-control study within a European prospective cohort study. Gut 2009, 58, 1606-1611. [PubMed]

5. Ananthakrishnan, A.N.; Khalili, H.; Konijeti, G.G.; Higuchi, L.M.; de Silva, P.; Fuchs, C.S.; Willett, W.C.; Richter, J.M.; Chan, A.T. Long-term intake of dietary fat and risk of ulcerative colitis and Crohn's disease. Gut 2014, 63, 776-784. [CrossRef] [PubMed]

6. Yates, C.M.; Calder, P.C.; Ed Rainger, G. Pharmacology and therapeutics of omega-3 polyunsaturated fatty acids in chronic inflammatory disease. Pharmacol. Ther. 2014, 141, 272-282. [CrossRef] [PubMed]

7. Fritsche, K. Fatty acids as modulators of the immune response. Annu. Rev. Nutr. 2006, 26, 45-73. [CrossRef] [PubMed]

8. Novak, T.E.; Babcock, T.A.; Jho, D.H.; Helton, W.S.; Espat, N.J. NF-kB inhibition by omega -3 fatty acids modulates LPS-stimulated macrophage TNF- $\alpha$ transcription. Am. J. Physiol. Lung Cell Mol. Physiol. 2003, 284, L84-L89. [CrossRef] [PubMed]

9. Yaqoob, P. Mechanisms underlying the immunomodulatory effects of n-3 PUFA. Proc. Nutr. Soc. 2010, 69, 311-315. [CrossRef] [PubMed]

10. Goldman, D.W.; Pickett, W.C.; Goetzl, E.J. Human neutrophil chemotactic and degranulating activities of leukotriene B5 (LTB5) derived from eicosapentaenoic acid. Biochem. Biophys. Res. Commun. 1983, 117, 282-288. [CrossRef]

11. Calder, P.C. Marine omega-3 fatty acids and inflammatory processes: Effects, mechanisms and clinical relevance. Biochim. Biophys. Acta 2015, 1851, 469-484. [CrossRef] [PubMed]

12. Serhan, C.N. Pro-resolving lipid mediators are leads for resolution physiology. Nature 2014, 510, 92-101. [CrossRef] [PubMed]

13. Lev-Tzion, R.; Griffiths, A.M.; Leder, O.; Turner, D. Omega 3 fatty acids (fish oil) for maintenance of remission in Crohn's disease. Cochrane Database Syst. Rev. 2014, 2, CD006320.

14. Turner, D.; Shah, P.S.; Steinhart, A.H.; Zlotkin, S.; Griffiths, A.M. Maintenance of remission in inflammatory bowel disease using omega-3 fatty acids (fish oil): A systematic review and meta-analyses. Inflamm. Bowel Dis. 2011, 17, 336-345. [CrossRef] [PubMed]

15. Aslan, A.; Triadafilopoulos, G. Fish oil fatty acid supplementation in active ulcerative colitis: A double-blind, placebo-controlled, crossover study. Am. J. Gastroenterol. 1992, 87, 432-437. [PubMed]

16. Stenson, W.F.; Cort, D.; Rodgers, J.; Burakoff, R.; DeSchryver-Kecskemeti, K.; Gramlich, T.L.; Beeken, W. Dietary supplementation with fish oil in ulcerative colitis. Ann. Intern. Med. 1992, 116, 609-614. [CrossRef] [PubMed]

17. Hawthorne, A.B.; Daneshmend, T.K.; Hawkey, C.J.; Belluzzi, A.; Everitt, S.J.; Holmes, G.K.; Malkinson, C.; Shaheen, M.Z.; Willars, J.E. Treatment of ulcerative colitis with fish oil supplementation: A prospective 12 month randomised controlled trial. Gut 1992, 33, 922-928. [CrossRef] [PubMed]

18. McCall, T.B.; O'Leary, D.; Bloomfield, J.; O’Moráin, C.A. Therapeutic potential of fish oil in the treatment of ulcerative colitis. Aliment. Pharmacol. Ther. 1989, 3, 415-424. [CrossRef] [PubMed]

19. Loeschke, K.; Ueberschaer, B.; Pietsch, A.; Gruber, E.; Ewe, K.; Wiebecke, B.; Heldwein, W.; Lorenz, R. n-3 fatty acids only delay early relapse of ulcerative colitis in remission. Dig. Dis. Sci. 1996, 41, 2087-2094. [CrossRef] [PubMed] 
20. Salomon, P.; Kornbluth, A.A.; Janowitz, H.D. Treatment of ulcerative colitis with fish oil n-3-omega-fatty acid: An open trial. J. Clin. Gastroenterol. 1990, 12, 157-161. [CrossRef] [PubMed]

21. Almallah, Y.Z.; Richardson, S.; O’Hanrahan, T.; Mowat, N.A.; Brunt, P.W.; Sinclair, T.S.; Ewen, S.; Heys, S.D.; Eremin, O. Distal procto-colitis, natural cytotoxicity, and essential fatty acids. Am. J. Gastroenterol. 1998, 93, 804-809. [CrossRef] [PubMed]

22. Dichi, I.; Frenhane, P.; Dichi, J.B.; Correa, C.R.; Angeleli, A.Y.; Bicudo, M.H.; Rodrigues, M.A.; Victória, C.R.; Burini, R.C. Comparison of omega-3 fatty acids and sulfasalazine in ulcerative colitis. Nutrition 2000, 16, 87-90. [CrossRef]

23. Lorenz, R.; Weber, P.C.; Szimnau, P.; Heldwein, W.; Strasser, T.; Loeschke, K. Supplementation with n-3 fatty acids from fish oil in chronic inflammatory bowel disease: A randomized placebo-controlled double-blind cross-over trial. J. Int. Med. 1989, 225, 225-232. [CrossRef]

24. Mate, J.; Castanos, R.; Garcia-Samaniego, J.; Pajares, J.M. Does dietary fish oil maintain the remission of Crohn's disease (CD): A study case control. Gastroenterology 1993, 100, 228.

25. Lorenz-Meyer, H.; Bauer, P.; Nicolay, C.; Schulz, B.; Purrmann, J.; Fleig, W.E.; Scheurlen, C.; Koop, I.; Pudel, V.; Carr, L. Omega-3 fatty acids and carbohydrate diet for maintenance of remission in Crohn's disease. Scan. J. Gastroenterol. 1996, 31, 778-785. [CrossRef]

26. Cheifetz, A.S.; Gianotti, R.; Luber, R.; Gibson, P.R. Complementary and alternative medicines used by patients with inflammatory bowel diseases. Gastroenterology 2017, 152, 415-429. [CrossRef] [PubMed]

27. Turner, D.; Steinhart, A.H.; Griffiths, A.M. Omega 3 fatty acids (fish oil) for maintenance of remission in ulcerative colitis. Cochrane Database Syst. Rev. 2007, 3, CD006443.

28. De Ley, M.; de Vos, R.; Hommes, D.W.; Stokkers, P. Fish oil for induction of remission in ulcerative colitis. Cochrane Database Syst. Rev. 2007, 4, CD005986.

29. Appleyard, C.B.; Hernández, G.; Rios-Bedoya, C.F. Basic epidemiology of inflammatory bowel disease in Puerto Rico. Inflamm. Bowel. Dis. 2004, 10, 106-111. [CrossRef] [PubMed]

30. Charlebois, A.; Rosenfeld, G.; Bressler, B. The Impact of Dietary Interventions on the Symptoms of Inflammatory Bowel Disease: A Systematic Review. Crit. Rev. Food. Sci. Nutr. 2016, 56, 1370-1378. [CrossRef] [PubMed]

31. Damas, O.M.; Jahann, D.A.; Reznik, R.; McCauley, J.L.; Tamariz, L.; Deshpande, A.R.; Abreu, M.T.; Sussman, D.A. Phenotypic manifestations of inflammatory bowel disease differ between Hispanics and non-Hispanic whites: Results of a large cohort study. Am. J. Gastroenterol. 2013, 108, 231-239. [CrossRef] [PubMed]

32. Eaton, S.B.; Konner, M. A consideration of its nature and current implications. N. Engl. J. Med. 1985, 312, 283-289. [CrossRef] [PubMed]

33. Konner, M.; Eaton, S.B. Paleolithic nutrition: Twenty-five years later. Nutr. Clin. Pract. 2010, 25, 594-602. [CrossRef] [PubMed]

34. Davis, D.L. Paleolithic diet, evolution, and carcinogens. Science 1987, 238, 1633-1634. [CrossRef] [PubMed]

35. Jew, S.; AbuMweis, S.S.; Jones, P.J. Evolution of the human diet: Linking our ancestral diet to modern functional foods as a means of chronic disease prevention. J. Med. Food 2009, 12, 925-934. [CrossRef] [PubMed]

36. Whalen, K.A.; McCullough, M.L.; Flanders, W.D.; Hartman, T.J.; Judd, S.; Bostick, R.M. Paleolithic and mediterranean diet pattern scores are inversely associated with biomarkers of inflammation and oxidative balance in adults. J. Nutr. 2016, 146, 1217-1226. [CrossRef] [PubMed]

37. Simopoulos, A.P. The importance of the ratio of omega-6/omega-3 essential fatty acids. Biomed. Pharmacother. 2002, 56, 365-379. [CrossRef]

38. Von Schacky, C.; Fischer, S.; Weber, P.C. Long-term effects of dietary marine omega-3 fatty acids upon plasma and cellular lipids, platelet function, and eicosanoid formation in humans. J. Clin. Investig. 1985, 76, 1231-1626. [CrossRef] [PubMed]

39. Reif, S.; Klein, I.; Lubin, F.; Farbstein, M.; Hallak, A.; Gilat, T. Pre-illness dietary factors in inflammatory bowel disease. Gut 1997, 40, 754-760. [CrossRef] [PubMed]

40. Geerling, B.J.; Dagnelie, P.C.; Badart-Smook, A.; Russel, M.G.; Stockbrügger, R.W.; Brummer, R.J. Diet as a risk factor for the development of ulcerative colitis. Am. J. Gastroenterol. 2000, 95, 1008-1013. [CrossRef] [PubMed] 
41. Shoda, R.; Matsueda, K.; Yamato, S.; Umeda, N. Epidemiologic analysis of Crohn disease in Japan: Increased dietary intake of n-6 polyunsaturated fatty acids and animal protein relates to the increased incidence of Crohn disease in Japan. Am. J. Clin. Nutr. 1996, 63, 741-745. [PubMed]

42. John, S.; Luben, R.; Shrestha, S.S.; Welch, A.; Khaw, K.T.; Hart, A.R. Dietary n-3 polyunsaturated fatty acids and the aetiology of ulcerative colitis: A UK prospective cohort study. Eur. J. Gastroenterol. Hepatol. 2010, 22, 602-606. [CrossRef] [PubMed]

43. Chan, S.S.; Luben, R.; Olsen, A.; Tjonneland, A.; Kaaks, R.; Lindgren, S.; Grip, O.; Bergmann, M.M.; Boeing, H.; Hallmans, G.; et al. Association between high dietary intake of the n-3 polyunsaturated fatty acid docosahexaenoic acid and reduced risk of Crohn's disease. Aliment. Pharmacol. Ther. 2014, 39, 834-842. [CrossRef] [PubMed]

44. Hou, J.K.; Abraham, B.; El-Serag, H. Dietary intake and risk of developing inflammatory bowel disease: A systematic review of the literature. Am. J. Gastroenterol. 2011, 106, 563-573. [CrossRef] [PubMed]

45. Calder, P.C. Polyunsaturated fatty acids, inflammatory processes and inflammatory bowel diseases. Mol. Nutr. Food Res. 2008, 52, 885-897. [CrossRef] [PubMed]

46. Pearl, D.S.; Masoodi, M.; Eiden, M.; Brümmer, J.; Gullick, D.; McKeever, T.M.; Whittaker, M.A.; Nitch-Smith, H.; Brown, J.F.; Shute, J.K.; et al. Altered colonic mucosal availability of n-3 and n-6 polyunsaturated fatty acids in ulcerative colitis and the relationship to disease activity. J. Crohns Colitis 2014, 8, 70-79. [CrossRef] [PubMed]

47. Lee, T.H.; Hoover, R.L.; Williams, J.D.; Sperling, R.I.; Ravalese, J., 3rd; Spur, B.W.; Robinson, D.R.; Corey, E.J.; Lewis, R.A.; Austen, K.F. Effect of dietary enrichment with eicosapentaenoic and docosahexaenoic acids on in vitro neutrophil and monocyte leukotriene generation and neutrophil function. N. Engl. J. Med. 1985, 312, 1217-1224. [CrossRef] [PubMed]

48. Endres, S.; Ghorbani, R.; Kelley, V.E.; Georgilis, K.; Lonnemann, G.; van der Meer, J.W.; Cannon, J.G.; Rogers, T.S.; Klempner, M.S.; Weber, P.C.; et al. The effect of dietary supplementation with n-3 polyunsaturated fatty acids on the synthesis of interleukin-1 and tumor necrosis factor by mononuclear cells. N. Engl. J. Med. 1989, 320, 265-271. [CrossRef] [PubMed]

49. Rees, D.; Miles, E.A.; Banerjee, T.; Wells, S.J.; Roynette, C.E.; Wahle, K.W.; Calder, P.C. Dose-related effects of eicosapentaenoic acid on innate immune function in healthy humans: A comparison of young and older men. Am. J. Clin. Nutr. 2006, 83, 331-342. [PubMed]

50. McDougle, D.R.; Watson, J.E.; Abdeen, A.A.; Adili, R.; Caputo, M.P.; Krapf, J.E.; Johnson, R.W.; Kilian, K.A.; Holinstat, M.; Das, A. Anti-inflammatory w-3 endocannabinoid epoxides. Proc. Natl. Acad. Sci. USA 2017, 114, E6034-E6043. [CrossRef] [PubMed]

51. Vanden Berghe, W.; Vermeulen, L.; Delerive, P.; De Bosscher, K.; Staels, B.; Haegeman, G. A paradigm for gene regulation: Inflammation, NF-êB and PPAR. Adv. Exp. Med. Biol. 2003, 544, 181-196. [PubMed]

52. Moraes, L.A.; Piqueras, L.; Bishop-Bailey, D. Peroxisome proliferator-activated receptors and inflammation. Pharmacol. Ther. 2006, 110, 371-385. [CrossRef] [PubMed]

53. Dubuquoy, L.; Jansson, E.A.; Deeb, S.; Rakotobe, S.; Karoui, M.; Colombel, J.F.; Auwerx, J.; Pettersson, S.; Desreumaux, P. Impaired expression of peroxisome proliferator-activated receptor $\gamma$ in ulcerative colitis. Gastroenterology 2003, 124, 1265-1276. [CrossRef]

54. Hassan, A.; Ibrahim, A.; Mbodji, K.; Coëffier, M.; Ziegler, F.; Bounoure, F.; Chardigny, J.M.; Skiba, M.; Savoye, G.; Déchelotte, P.; et al. An $\alpha$-linolenic acid-rich formula reduces oxidative stress and inflammation by regulating NF-kB in rats with TNBS-induced colitis. J. Nutr. 2010, 140, 1714-1721. [CrossRef] [PubMed]

55. Kliewer, S.A.; Sundseth, S.S.; Jones, S.A.; Brown, P.J.; Wisely, G.B.; Koble, C.S.; Devchand, P.; Wahli, W.; Willson, T.M.; Lenhard, J.M.; et al. Fatty acids and eicosanoids regulate gene expression through direct interactions with peroxisome proliferator-activated receptors $\alpha$ and $\gamma$. Proc. Natl. Acad. Sci. USA 1997, 94, 4318-4323. [CrossRef] [PubMed]

56. Knoch, B.; Barnett, M.P.; Zhu, S.; Park, Z.A.; Nones, K.; Dommels, Y.E.; Knowles, S.O.; McNabb, W.C.; Roy, N.C. Genome-wide analysis of dietary eicosapentaenoic acid- and oleic acid-induced modulation of colon inflammation in interleukin-10 gene-deficient mice. J. Nutrigenet. Nutrigenomi. 2009, 2, 9-28. [CrossRef] [PubMed]

57. Costea, I.; Mack, D.R.; Lemaitre, R.N.; Israel, D.; Marcil, V.; Ahmad, A.; Amre, D.K. Interactions between the dietary polyunsaturated fatty acid ratio and genetic factors determine susceptibility to pediatric Crohn's disease. Gastroenterology 2014, 146, 929-931. [CrossRef] [PubMed] 
58. Corcos, L.; Lucas, D.; Le Jossic-Corcos, C.; Dréano, Y.; Simon, B.; Plée-Gautier, E.; Amet, Y.; Salaün, J.P. Human cytochrome P450 4F3: Structure, functions, and prospects. Drug Metabol. Drug Interact. 2012, 27, 63-71. [CrossRef] [PubMed]

59. Kettunen, J.; Tukiainen, T.; Sarin, A.P.; Ortega-Alonso, A.; Tikkanen, E.; Lyytikäinen, L.P.; Kangas, A.J.; Soininen, P.; Würtz, P.; Silander, K.; et al. Genome-wide association study identifies multiple loci influencing human serum metabolite levels. Nat. Genet. 2012, 44, 269-276. [CrossRef] [PubMed]

60. Zhang, J.Y.; Kothapalli, K.S.; Brenna, J.T. Desaturase and elongase-limiting endogenous long-chain polyunsaturated fatty acid biosynthesis. Curr. Opin. Clin. Nutr. Metab. Care 2016, 19, 103-110. [CrossRef] [PubMed]

61. Grimble, R.F.; Howell, W.M.; O’Reilly, G.; Turner, S.J.; Markovic, O.; Hirrell, S.; East, J.M.; Calder, P.C. The ability of fish oil to suppress tumor necrosis factor $\alpha$ production by peripheral blood mononuclear cells in healthy men is associated with polymorphisms in genes that influence tumor necrosis factor $\alpha$ production. Am. J. Clin. Nutr. 2002, 76, 454-459. [PubMed]

62. Sperling, R.I.; Benincaso, A.I.; Knoell, C.T.; Larkin, J.K.; Austen, K.F.; Robinson, D.R. Dietary omega-3 polyunsaturated fatty acids inhibit phosphoinositide formation and chemotaxis in neutrophils. J. Clin. Investig. 1993, 91, 651-660. [CrossRef] [PubMed]

63. Calder, P.C. Omega-3 fatty acids and inflammatory processes. Nutrients 2010, 2, 355-374. [CrossRef] [PubMed]

64. De Caterina, R.; Cybulsky, M.I.; Clinton, S.K.; Gimbrone, M.A., Jr.; Libby, P. The omega-3 fatty acid docosahexaenoate reduces cytokine-induced expression of proatherogenic and proinflammatory proteins in human endothelial cells. Arterioscler. Thromb. 1994, 14, 1829-1836. [CrossRef] [PubMed]

65. Baumgart, D.C.; Carding, S.R. Inflammatory bowel disease: Cause and immunobiology. Lancet 2007, 369, 1627-1640. [CrossRef]

66. Kostic, A.D.; Xavier, R.J.; Gevers, D. The microbiome in inflammatory bowel disease: Current status and the future ahead. Gastroenterology 2014, 146, 1489-1499. [CrossRef] [PubMed]

67. Cario, E. Toll-like receptors in inflammatory bowel diseases: A decade later. Inflamm. Bowel Dis. 2010, 16, 1583-1597. [CrossRef] [PubMed]

68. Hugot, J.P.; Chamaillard, M.; Zouali, H.; Lesage, S.; Cézard, J.P.; Belaiche, J.; Almer, S.; Tysk, C.; O'Morain, C.A.; Gassull, M.; et al. Association of NOD2 leucine-rich repeat variants with susceptibility to Crohn's disease. Nature 2001, 411, 599-603. [CrossRef] [PubMed]

69. Yamamoto, S.; Ma, X. Role of Nod2 in the development of Crohn's disease. Microbes Infect. 2009, 11, 912-918. [CrossRef] [PubMed]

70. Lee, J.Y.; Plakidas, A.; Lee, W.H.; Heikkinen, A.; Chanmugam, P.; Bray, G.; Hwang, D.H. Differential modulation of Toll-like receptors by fatty acids: Preferential inhibition by $\mathrm{n}-3$ polyunsaturated fatty acids. J. Lipid Res. 2003, 44, 479-486. [CrossRef] [PubMed]

71. Ibrahim, A.; Mbodji, K.; Hassan, A.; Aziz, M.; Boukhettala, N.; Coëffier, M.; Savoye, G.; Déchelotte, P.; Marion-Letellier, R. Anti-inflammatory and anti-angiogenic effect of long chain n-3 polyunsaturated fatty acids in intestinal microvascular endothelium. Clin. Nutr. 2011, 30, 678-687. [CrossRef] [PubMed]

72. Allam-Ndoul, B.; Guénard, F.; Barbier, O.; Vohl, M.C. Effect of n-3 fatty acids on the expression of inflammatory genes in THP-1 macrophages. Lipids Health Dis. 2016, 15, 69. [CrossRef] [PubMed]

73. Martinon, F.; Mayor, A.; Tschopp, J. The inflammasomes: Guardians of the body. Annu. Rev. Immunol. 2009, 27, 229-265. [CrossRef] [PubMed]

74. Corridoni, D.; Arseneau, K.O.; Cifone, M.G.; Cominelli, F. The dual role of Nod-like receptors in mucosal innate immunity and chronic intestinal inflammation. Front. Immunol. 2014, 5, 317. [CrossRef] [PubMed]

75. Wen, H.; Gris, D.; Lei, Y.; Jha, S.; Zhang, L.; Huang, M.T.; Brickey, W.J.; Ting, J.P. Fatty acid-induced NLRP3-ASC inflammasome activation interferes with insulin signaling. Nat. Immunol. 2011, 12, 408-415. [CrossRef] [PubMed]

76. Yan, Y.; Jiang, W.; Spinetti, T.; Tardivel, A.; Castillo, R.; Bourquin, C.; Guarda, G.; Tian, Z.; Tschopp, J.; Zhou, R. Omega-3 fatty acids prevent inflammation and metabolic disorder through inhibition of NLRP3 inflammasome activation. Immunity 2013, 38, 1154-1163. [CrossRef] [PubMed]

77. De Filippo, C.; Cavalieri, D.; Di Paola, M.; Ramazzotti, M.; Poullet, J.B.; Massart, S.; Collini, S.; Pieraccini, G.; Lionetti, P. Impact of diet in shaping gut microbiota revealed by a comparative study in children from Europe and rural Africa. Proc. Natl. Acad. Sci. USA 2010, 107, 14691-14696. [CrossRef] [PubMed] 
78. Jansson, J.; Willing, B.; Lucio, M.; Fekete, A.; Dicksved, J.; Halfvarson, J.; Tysk, C.; Schmitt-Kopplin, P. Metabolomics reveals metabolic biomarkers of Crohn's disease. PLoS ONE 2009, 4, e6386. [CrossRef] [PubMed]

79. Ghosh, S.; DeCoffe, D.; Brown, K.; Rajendiran, E.; Estaki, M.; Dai, C.; Yip, A.; Gibson, D.L. Fish oil attenuates omega-6 polyunsaturated fatty acid-induced dysbiosis and infectious colitis but impairs LPS dephosphorylation activity causing sepsis. PLoS ONE 2013, 8, e55468. [CrossRef] [PubMed]

80. Piazzi, G.; D’Argenio, G.; Prossomariti, A.; Lembo, V.; Mazzone, G.; Candela, M.; Biagi, E.; Brigidi, P.; Vitaglione, P.; Fogliano, V.; et al. Eicosapentaenoic acid free fatty acid prevents and suppresses colonic neoplasia in colitis-associated colorectal cancer acting on Notch signaling and gut microbiota. Int. J. Cancer 2014, 135, 2004-2013. [CrossRef] [PubMed]

81. Prossomariti, A.; Scaioli, E.; Piazzi, G.; Fazio, C.; Bellanova, M.; Biagi, E.; Candela, M.; Brigidi, P.; Consolandi, C.; Balbi, T.; et al. Short-term treatment with eicosapentaenoic acid improves inflammation and affects colonic differentiation markers and microbiota in patients with ulcerative colitis. Sci. Rep. 2017, 7, 7458. [CrossRef] [PubMed]

82. Rodríguez-Carrio, J.; Salazar, N.; Margolles, A.; González, S.; Gueimonde, M.; de Los Reyes-Gavilán, C.G.; Suárez, A. Free fatty acids profiles are related to gut microbiota signatures and short-chain fatty acids. Front. Immunol. 2017, 8, 823. [CrossRef] [PubMed]

83. Watson, H.; Mitra, S.; Croden, F.C.; Taylor, M.; Wood, H.M.; Perry, S.L.; Spencer, J.A.; Quirke, P.; Toogood, G.J.; Lawton, C.L.; et al. A randomised trial of the effect of omega-3 polyunsaturated fatty acid supplements on the human intestinal microbiota. Gut 2017. [CrossRef] [PubMed]

84. Hong, S.K.; Maltz, B.E.; Coburn, L.A.; Slaughter, J.C.; Chaturvedi, R.; Schwartz, D.A.; Wilson, K.T. Increased serum levels of L-arginine in ulcerative colitis and correlation with disease severity. Inflamm. Bowel Dis. 2010, 16, 105-111. [CrossRef] [PubMed]

85. Beyazit, Y.; Purnak, T.; Kekilli, M. Role of nitric oxide in the treatment of non-alcoholic fatty liver by omega-3 fatty acids. Aliment. Pharmacol. Ther. 2010, 32, 303-304. [CrossRef] [PubMed]

86. Middleton, S.J.; Naylor, S.; Woolner, J.; Hunter, J.O. A double-blind, randomized, placebo-controlled trial of essential fatty acid supplementation in the maintenance of remission of ulcerative colitis. Aliment. Pharmacol. Ther. 2002, 16, 1131-1135. [CrossRef] [PubMed]

87. Best, W.R.; Becktel, J.M.; Singleton, J.W.; Kern, F. Development of a Crohn's disease activity Index. Gastroenterolology 1976, 70, 439-444.

88. Belluzzi, A. N-3 fatty acids for the treatment of inflammatory bowel diseases. Proc. Nutr. Soc. 2002, 61, 391-395. [CrossRef] [PubMed]

89. Marion-Letellier, R.; Savoye, G.; Beck, P.L.; Panaccione, R.; Ghosh, S. Polyunsaturated fatty acids in inflammatory bowel diseases: A reappraisal of effects and therapeutic approaches. Inflamm. Bowel Dis. 2013, 19, 650-661. [CrossRef] [PubMed]

90. Brignola, C.; Campieri, M.; Bazzocchi, G.; Farruggia, P.; Tragnone, A.; Lanfranchi, G.A. A laboratory index for predicting relapse in asymptomatic patients with Crohn's disease. Gastroenterology 1986, 91, 1490-1494. [CrossRef]

91. Belluzzi, A.; Brignola, C.; Campieri, M.; Pera, A.; Boschi, S.; Miglioli, M. Effect of an enteric-Coated fish oil preparation on relapses in Crohn's disease. N. Engl. J. Med. 1996, 334, 1557-1560. [CrossRef] [PubMed]

92. Feagan, B.G.; Sandborn, W.J.; Mittmann, U.; Bar-Meir, S.; D’Haens, G.; Bradette, M.; Cohen, A.; Dallaire, C.; Ponich, T.P.; McDonald, J.W.; et al. Omega-3 free fatty acids for the maintenance of remission in Crohn disease: The EPIC Randomized Controlled Trials. JAMA 2008, 299, 1690-1697. [CrossRef] [PubMed]

93. Candy, S.; Wright, J.; Gerber, M.; Adams, G.; Gerig, M.; Goodman, R. A controlled double blind study of azathioprine in the management of Crohn's disease. Gut 1995, 37, 674-678. [CrossRef] [PubMed]

94. Romano, C.; Cucchiara, S.; Barabino, A.; Annese, V.; Sferlazzas, C. Usefulness of omega-3 fatty acid supplementation in addition to mesalazine in maintaining remission in pediatric Crohn's disease: A double-blind; randomized; placebo-controlled study. World J. Gastroenterol. 2005, 11, 7118-7121. [CrossRef] [PubMed]

95. Uchiyama, K.; Nakamura, M.; Odahara, S.; Koido, S.; Katahira, K.; Shiraishi, H.; Ohkusa, T.; Fujise, K.; Tajiri, H. N-3 polyunsaturated fatty acid diet therapy for patients with inflammatory bowel disease. Inflamm. Bowel Dis. 2010, 16, 1696-1707. [CrossRef] [PubMed] 
96. Scaioli, E.; Sartini, A.; Bellanova, M.; Campieri, M.; Festi, D.; Bazzoli, F.; Belluzzi, A. Eicosapentaenoic acid reduces fecal calprotectin and prevents relapse in ulcerative colitis patients: A placebo-controlled trial. Clin. Gastroenterol. Hepatol. 2017. under review.

97. Sipponen, T.; Kolho, K.L. Fecal calprotectin in diagnosis and clinical assessment of inflammatory bowel disease. Scand. J. Gastroenterol. 2015, 50, 74-80. [CrossRef] [PubMed]

98. Olsen, S.F.; Sørensen, J.D.; Secher, N.J.; Hedegaard, M.; Henriksen, T.B.; Hansen, H.S.; Grant, A. Randomised controlled trial of effect of fish-oil supplementation on pregnancy duration. Lancet 1992, 339, 1003-1007. [CrossRef]

99. Schuchardt, J.P.; Hahn, A. Bioavailability of long-chain omega-3 fatty acids. PLEFA 2013, 89, 1-8. [CrossRef] [PubMed]

100. Lawson, L.D.; Hughes, B.G. Human absorption of fish oil fatty acids as triacylglycerols, free acids, or ethyl esters. Biochem. Biophys. Res. Commun. 1988, 152, 328-335. [CrossRef]

101. Belluzzi, A.; Brignola, C.; Campieri, M.; Camporesi, E.P.; Gionchetti, P.; Rizzello, F.; Belloli, C.; De Simone, G.; Boschi, S.; Miglioli, M.; et al. Effects of new fish oil derivative on fatty acid phospholipid-membrane pattern in a group of Crohn's disease patients. Dig. Dis. Sci. 1994, 39, 2589-2594. [CrossRef] [PubMed]

102. Scaioli, E.; Cardamone, C.; Liverani, E.; Munarini, A.; Hull, M.A.; Belluzzi, A. The pharmacokinetic profile of a new gastroresistant capsule preparation of eicosapentaenoic acid as the free fatty acid. BioMed. Res. Int. 2015, 2015, 360825. [CrossRef] [PubMed]

103. Nakanishi, M.; Hanley, M.P.; Mathias, G.; Sciavolino, F.; Hull, M.; Rosenberg, D.W. 652-A novel derivative of eicosapentaenoic acid reduces intestinal tumor burden in the APC ${ }^{\Delta 14 /+}$ mouse model of familial adenomatous polyposis. Gastroenterology 2017, 152, S142. [CrossRef]

104. Maki, K.C.; Bobotas, G.; Dicklin, M.R.; Huebner, M.; Keane, W.F. Effects of MAT9001 containing eicosapentaenoic acid and docosapentaenoic acid, compared to eicosapentaenoic acid ethyl esters, on triglycerides, lipoprotein cholesterol, and related variables. J. Clin. Lipidol. 2017, 11, 102-109. [CrossRef] [PubMed]

105. Vestland, T.L.; Asberg, A.; Klaveness, A.J.; Klaveness, J. Bioavailability of eicosapentaenoic acid and docosahexaenoic acid from omega-3 tablets. JSM Bioequiv. Bioavailab. 2017, 1, 1001.

(C) 2017 by the authors. Licensee MDPI, Basel, Switzerland. This article is an open access article distributed under the terms and conditions of the Creative Commons Attribution (CC BY) license (http:/ / creativecommons.org/licenses/by/4.0/). 